\title{
Review \\ MicroRNAs: Potential Targets for Developing Stress-Tolerant Crops
}

\author{
Saurabh Chaudhary ${ }^{1, *(\mathbb{D}}$, Atul Grover ${ }^{2}$ and Prakash Chand Sharma ${ }^{3, *}$ \\ 1 Cardiff School of Biosciences, Cardiff University, Cardiff CF10 3AT, UK \\ 2 Defence Institute of Bio-Energy Research, Defence Research and Development Organisation (DRDO), \\ Haldwani 263139, India; atul@diber.drdo.in \\ 3 University School of Biotechnology, Guru Gobind Singh Indraprastha University, New Delhi 110078, India \\ * Correspondence: Chaudharys6@cardiff.ac.uk (S.C.); prof.pcsharma@ipu.ac.in (P.C.S.)
}

Citation: Chaudhary, S.; Grover, A.; Sharma, P.C. MicroRNAs: Potential Targets for Developing StressTolerant Crops. Life 2021, 11, 289. https://doi.org/10.3390/life11040289

Academic Editors: Tatyana Savchenko and Andrej Frolov

Received: 9 March 2021

Accepted: 26 March 2021

Published: 28 March 2021

Publisher's Note: MDPI stays neutral with regard to jurisdictional claims in published maps and institutional affiliations.

Copyright: (C) 2021 by the authors. Licensee MDPI, Basel, Switzerland. This article is an open access article distributed under the terms and conditions of the Creative Commons Attribution (CC BY) license (https:/ / creativecommons.org/licenses/by/ $4.0 /)$.

\begin{abstract}
Crop yield is challenged every year worldwide by changing climatic conditions. The forecasted climatic scenario urgently demands stress-tolerant crop varieties to feed the ever-increasing global population. Molecular breeding and genetic engineering approaches have been frequently exploited for developing crops with desired agronomic traits. Recently, microRNAs (miRNAs) have emerged as powerful molecules, which potentially serve as expression markers during stress conditions. The miRNAs are small non-coding endogenous RNAs, usually 20-24 nucleotides long, which mediate post-transcriptional gene silencing and fine-tune the regulation of many abioticand biotic-stress responsive genes in plants. The miRNAs usually function by specifically pairing with the target mRNAs, inducing their cleavage or repressing their translation. This review focuses on the exploration of the functional role of miRNAs in regulating plant responses to abiotic and biotic stresses. Moreover, a methodology is also discussed to mine stress-responsive miRNAs from the enormous amount of transcriptome data available in the public domain generated using next-generation sequencing (NGS). Considering the functional role of miRNAs in mediating stress responses, these molecules may be explored as novel targets for engineering stress-tolerant crop varieties.
\end{abstract}

Keywords: microRNA; abiotic stresses; biotic stresses; crop improvement; NGS; transcriptome

\section{Introduction}

Increasing global population and livestock demand a substantial increase in the production of food and fodder. According to the United Nations Population Division, the global population will touch the mark of 8.3 billion by 2030 . To serve better quality food and feed the ever-growing population is the imperative task for the scientific community in the 21st century. Furthermore, changing climatic conditions adversely affect agricultural productivity worldwide. Extreme climatic conditions are the major cause of abiotic and biotic stresses, and more than 50\% crop yield loss per annum worldwide [1]. Therefore, plant biology research activities require the development of high yielding, stress-tolerant crop varieties with desired nutrients to face food security challenges in the coming times. Classical crop breeding has been practiced for hundreds of years to generate high yielding crop varieties, and significant progress has been made to utilize genetic variations available in germplasm resources to develop crops with desirable agronomical traits. However, the long generation time and self-crossing of crops make the classical breeding techniques more time consuming and cumbersome. In that scenario, alternate efficient strategies are required to develop crop varieties with high yield and stress resistance. Genetic engineering is one such strategy that is currently being utilized and practiced worldwide to enhance the yield of crops through the development of environmental stress- and disease-resistant crop varieties [2]. However, since a single trait might be controlled by many genes or vice-versa, the so-called pleiotropic effect makes the agronomical traits genetically complex. Therefore, 
improving a trait via genetic engineering sometimes may adversely affect other important traits. Moreover, many agronomical traits such as high yield and stress tolerance are regulated by a group of genes or pathways, making selection of gene(s) for desirable trait(s) rather difficult. Thus, the manipulation of agronomical traits to improve crop production requires genetic modulators that act precisely and target in a specific manner.

In the recent past, microRNAs (miRNAs) emerged as a novel target in the field of genetic engineering and have been exploited to develop high yield and stress-tolerant crop varieties [3-6]. MiRNAs are 20-24 nucleotide long non-coding endogenous regulatory RNAs which regulate many biological processes by gene silencing at the transcriptional and post-transcriptional level [7]. The miRNAs induce gene regulation through pairing and cleavage of their targeted mRNA or by inhibiting protein translation [7]. In plants, primary miRNA (pri-miRNA) is encoded by endogenous miRNA coding genes, transcribed by RNA polymerase II (Pol II). After a series of enzymatic reactions, pri-miRNAs fold into a stem-loop secondary structure to form mature miRNAs, which pair with respective target mRNAs/transcripts to destabilize them or inhibit protein translation [7-9].Several studies in the recent past have suggested versatile roles of miRNAs in plants, where they are involved in almost all biological and metabolic processes, including plant growth and development timing, tissue and organ differentiation, plant architecture, organ polarity, and response to various abiotic and biotic stresses [7,10-14]. Moreover, many studies have reported the differential expression of miRNAs and their targeted genes during different stages of plant development and tissue differentiation [15-18], organ phase transition [16], and under various environmental stresses $[4,19,20]$. The differential expression of miRNA further helps in the selection and identification of miRNAs and their target genes responsible for agronomical traits of interest.

Evidence has been collected in the recent past from miRNA analysis in various plant species including crops such as rice, maize, wheat, sorghum, sunflower, and cotton under different stresses, suggesting the potential role of miRNAs in regulating stress response in plants [4,11,21-25]. Manipulation of a single miRNA may enhance tolerance to multiple abiotic stresses in plants. For instance, overexpression of miR408 in Arabidopsis enhanced tolerance to salinity, cold, and oxidative stress [26]. Similarly, various miRNAs have been reported with altered expression in response to various fungal and viral infections in crop plants $[27,28]$. Therefore, plant miRNAs may serve as major candidates for further enhancing our understanding of plant stress responses at the molecular level [3,4]. Understanding plant miRNA regulatory pathways equips us with novel tools for genetic engineering to further improve crop yield, quality, and abiotic and biotic stress tolerance in crop varieties.

\section{Biogenesis and Mode of Action of Plant miRNAs}

The biogenesis of miRNAs is initiated inside the nucleus. A brief graphical representation of the biogenesis of plant miRNAs is provided in Figure 1. In general, genes encoding plant miRNAs, called microRNA genes (MIR genes), are found in intergenic areas or in antisense/sense orientation within introns of other genes [7]. The MIR genes are transcribed by RNA polymerase II to form a long RNA transcript called pri-miRNA [7]. Like other transcripts, the pri-miRNAs are capped at $5^{\prime}$ end and polyadenylated at $3^{\prime}$ end. The partial sequence of long single stranded pri-miRNA folds into a perfectly stem-loop structure, which is stabilized by RNA-binding protein, DAWDLE (DDL), to form precursor miRNA (pre-miRNA) [7,11]. The one arm of the stem-loop structure of pre-miRNA represents the mature miRNA sequence, which is further recognized by an endoribonuclease called Dicer-like (DCL1), an RNAIII type enzyme, with other proteins such as HYPONASTIC LEAVES 1 (HYL1), and SERRATE (SE) [29,30]. The DCL, HYL1, and SE processed the stem-loop structure of pre-miRNA to generate miRNA:miRNA* duplex structure inside the nucleus [7,29-31]. To stabilize and protect this newly synthesized miRNA:miRNA* duplex from degradation, it is methylated at $3^{\prime}$ terminus by a small RNA methyltransferase protein named HUA ENHANCER 1 (HEN1) and exported to the cytoplasm with the help of HASTY (HST1), a plant homolog of animal EXPORTIN-5 [32-35]. 


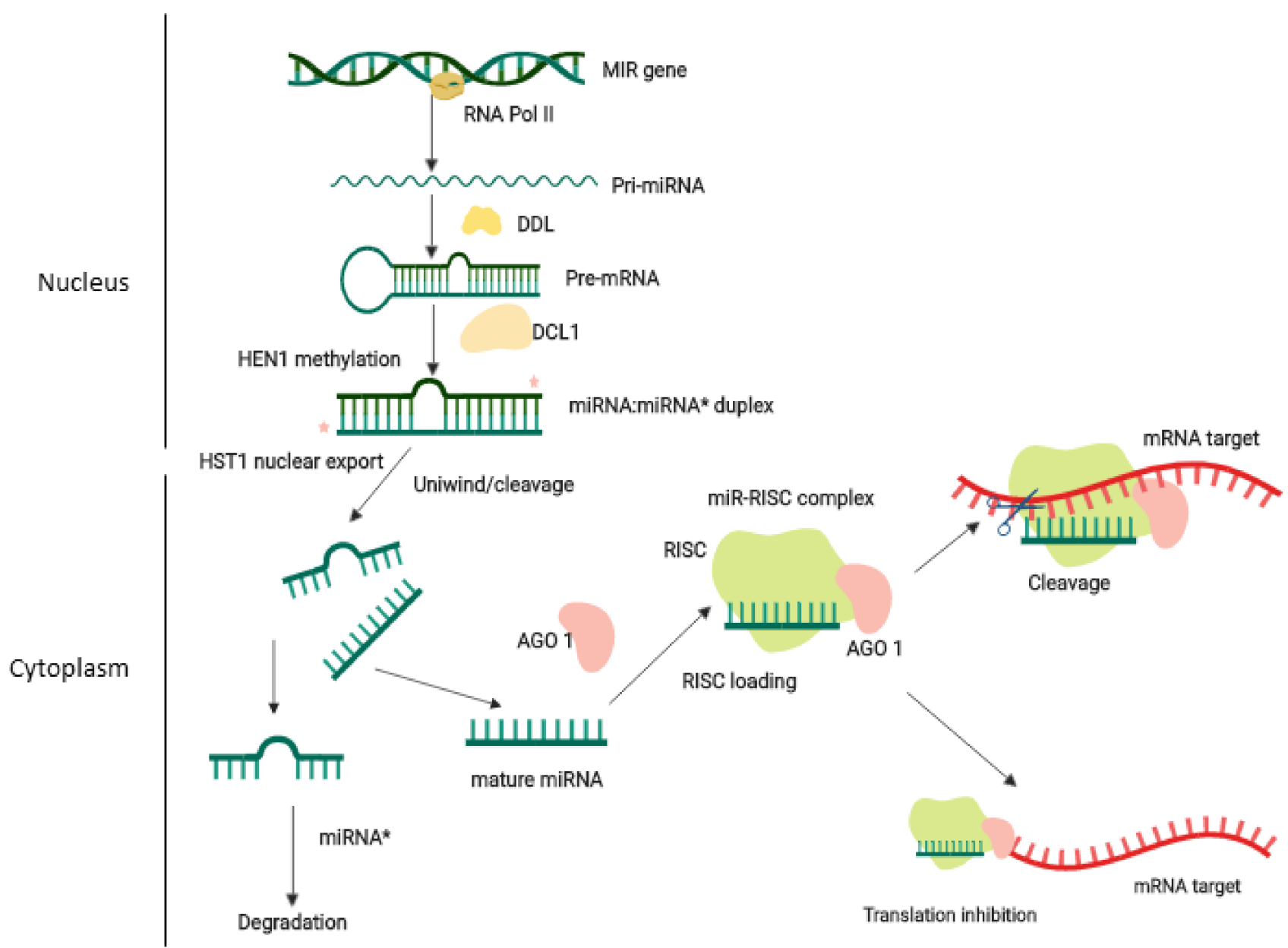

Figure 1. MicroRNA (miRNA) biogenesis and mode of action. Briefly, a miRNA gene (MIR gene), is transcribed into long single stranded preliminary-miRNA (pri-miRNA) transcript with the help of RNA polymerase II (RNA Pol II) in the nucleus. The pri-miRNA is converted into stem loop structure called precursor-miRNA (pre-miRNA), which is stabilized by the DAWDLE (DDL) enzyme. The Dicer-like 1 (DCL1), with the help of other proteins, generates miRNA:miRNA* duplex structure from pre-miRNA. The $3^{\prime}$ ends of miRNA:miRNA* duplex are methylated (stars) by HUA ENHANCER 1 (HEN1) and exported to the cytoplasm with the help of HASTY (HST1) enzyme. In the cytoplasm, the duplex is cleaved into mature miRNA from one strand, and the other strand miRNA* gets degraded. The mature miRNA is further processed by ARGONAUTE 1 (AGO1) and loaded into RNA-induced gene silence complex (RISC) to form miR-RISC complex. Depending upon the complementary sequence of the target mRNA, miR-RISC complex acts either by cleaving target mRNA or by inhibiting its translation. The figure is created with BioRender app (https://app.biorender.com/; accessed on 30 April 2020).

Finally, the mature miRNA in cytoplasm unwinds and is loaded to RNA-induced gene silencing complex (RISC), where it regulates expression of genes by forming the miR-RISC complex. The miR-RISC complex is stabilized by the ARGONAUTE 1 (AGO1) protein. The miRNA:miRNA* duplex then primarily unwinds with the help of AGO1 protein, and one strand is directed to exosomes for degradation, whereas the other strand of mature miRNA remains attached to the RISC with AGO1 protein [36-38]. The mature miRNA finally guides the AGO1-containing RISC complex, either to direct site-specific cleavage of complimentary mRNA with high homology or inhibit the translation of the targeted mRNA by imperfect base pairing. Regarding gene regulation by miRNA, the previous assumption suggested that only mature miRNA inhibits the mRNAs and translation. However, recent studies have demonstrated that another miRNA* strand also has its own targeted mRNA and regulates expression of respective genes [39]. 
In the recent past, there has been an increase in the number of reports investigating the mechanism of miRNA-based regulation of gene expression $[5,40,41]$. Plant miRNAs generally regulate gene expression at transcriptional and post-transcriptional level through perfect complementary sequence pairing [11,40]. The two modes of mechanism include cleavage of target mRNA, which is the result of a perfect pairing, and translation inhibition, a consequence of imperfect pairing. In the first mode, miRNA cleaves the poly-(A) tail of the target mRNA leading to its destabilization and decay [11,40,42]. Additionally, miRNA helps to influence various biological processes at transcriptional level by silencing transcription activity and decreasing the level of random fluctuation in the transcripts' copy number $[5,43]$. Experimental data from overexpression or loss of function analyses suggest that miRNAs fine-tune the expression of diverse class regulatory genes. Approximately $66 \%$ and $24.2 \%$ of miRNA targets are transcription factors (TFs) and major class of $\mathrm{R}$ (resistance) genes suggesting the role of miRNAs in diverse gene regulatory networks and plant immune system [44].

\section{Mining of miRNAs}

Identification of MIR genes, miRNAs, and their target gene is the foremost step to elucidating the miRNA-mediated gene regulatory network and underlying mechanisms. The initial research on plant miRNA identification included direct cloning and sequencing of small RNA population strategies [33,45]. In the past decade, advancement in high-throughput sequencing, also called next generation sequencing (NGS) technology, and computational strategies, has enhanced the discovery of novel and conserved plant miRNAs dramatically in a tissue-, environment-, and time-specific manner. The NGS technology has revolutionized plant miRNA research by enabling genome-wide or transcriptome-wide identification of miRNAs with unrivalled coverage and depth $[5,41,46]$. Additionally, high sequence similarity with the target mRNAs and the conserved nature of miRNAs makes computational tools, such as Basic Local Alignment Tool (BLAST) (https: / / blast.ncbi.nlm.nih.gov / Blast.cgi, accessed on 9 March 2021) and other homologybased tools, an alternative approach for the identification of miRNAs in many crop plants [47-49].

\subsection{Next Generation Sequencing-Based Methods for Identification of miRNAs}

NGS technology, such as the RNA-sequencing (RNA-Seq) technique, is widely used for transcriptome profiling and differential gene expression analysis requiring isolation of poly(A)-tail mRNA. The presence of poly-(A) tail in pri-miRNA includes them in the mRNA population used for RNA-Seq. Since pri-miRNAs are not stable enough for sequencing, it is difficult to fish out pre-miRNAs directly from RNA-Seq libraries. However, the robust and high depth of the RNA-Seq technique enables the detection of lowly abundant and weakly expressed transcripts. Therefore, pri-miRNA could be identified in the RNA-Seq data, although the precise level and full length of pri-miRNA could not be predicted in the RNA-Seq data [46]. To overcome the problem of detection of full-length transcripts in RNA-Seq, its modification, called RNA-paired-end tag sequencing (RNAPET-Seq) [50,51], was evolved. RNA-PET-Seq enables capturing transcripts with $5^{\prime}$ and $3^{\prime}$ ends simultaneously and distinguishes the boundaries of transcription units, providing sufficient information to assemble full length transcripts [50,51]. The combination of RNA-Seq and PET-tags can serve as a high-throughput strategy to elucidate the MIR gene transcriptional regions and quantify the abundance of a pri-miRNA [46]. Another revolutionary modification in the RNA-Seq technique occurred with the introduction of small RNA-Sequencing (sRNA-Seq) [52,53]. Since the library for sRNA-Seq is prepared from small RNA, it enables quantification of the abundance of miRNA in plant tissues, in a condition- and time-dependent manner. Further, techniques such as double-stranded RNA-Sequencing (dsRNA-Seq) and single stranded RNA-Sequencing (ssRNA-Seq) have also been used in the discovery of miRNAs [54]. The dsRNA-Seq and ssRNA-Seq together allow to elucidate the stem loop structure of the pre-miRNA efficiently [46]. Another 
widely used high-throughput technique in miRNA research is degradome-sequencing (degradome-Seq) $[55,56]$. The major application of degradome-Seq facilitates the identification of truncated transcripts generated from endonucleolytic cleavages, guided by small RNAs and miRNAs. Therefore, the reads generated from degradome-Seq could provide the information of the slicing sites residue in miRNA specific to their target transcripts [46].

\subsection{In Silico Mining of miRNAs}

The present-day high-throughput techniques generate a huge amount of data from diverse plant species, including crop plants. All the data so generated have been deposited in public domains such as miRBase (http:/ / www.mirbase.org, accessed on 9 March 2021) [57,58], the Plant MicroRNA Database (PMRD; http:/ / mirnablog.com/plant-micrornadatabase-goesonline, accessed on 9 March 2021) [59], and the NCBI-Gene Expression Omnibus (GEO; http://www.ncbi.nlm.nih.gov/geo/, accessed on 9 March 2021) [60]. Moreover, the conserved nature of plant miRNA [31] provides reasonable results on homology-based in silico analysis of potential miRNAs and their target genes [61]. Additionally, the developments in computational biology approaches also provide significant support to handle a large amount of raw data and make it biologically meaningful. A schematic representation for in silico mining of miRNA is provided in Figure 2. Briefly, the sequence for mature plant miRNA can be downloaded from miRBase (http:/ / www.mirbase.org, accessed on 9 March 2021) [57,58], followed by removal of redundant miRNA sequences. The raw reads generated from NGS can also be downloaded from the public domain, such as NCBI-Gene Expression Omnibus (GEO; http:/ /www.ncbi.nlm.nih.gov/geo/, accessed on 9 March 2021) [60]. The reads after quality filters are assembled into contigs/singletons. The unique contigs/singletons are further subjected to nucleotide BLASTn (https:/ /blast.ncbi.nlm.nih.gov/Blast.cgi, accessed on 9 March 2021) with the unique plant miRNA to get aligned sequences. The candidate miRNA should fulfil the two criteria as described by Panda et al., (2014) [62]: (i) at least 18-nt length with no gap in between should be there in candidate miRNA, and (ii) the assembled sequences, which match closely to the known miRNAs, are to be selected for further study [62]. The aligned sequence is then further put to BLASTx with plant protein database (Uniport; https: / / www.uniprot.org/program/Plants, accessed on 9 March 2021) [63] to remove all coding sequences. After discarding the protein coding sequence, the secondary structure can be accessed using MFOLD software (http:/ / unafold.rna.albany.edu/?q=mfold, accessed on 9 March 2021) [64] with default parameters. The candidate pre-miRNA, left after discarding miRNA that failed in MFOLD criteria, could be considered as novel potential miRNAs. The novel potential miRNAs can further be used for the identification of their target genes based on complementary binding between miRNA and target gene sequences using the psRNATarget server (http://plantgrn.noble.org/psRNATarget/?dowhat=Help, accessed on 9 March 2021) [65]. Finally, gene ontology (GO) terms using QuickGO (https: / /www.ebi.ac.uk/QuickGO/, accessed on 9 March 2021) can be assigned to the target genes to validate their functionality. 


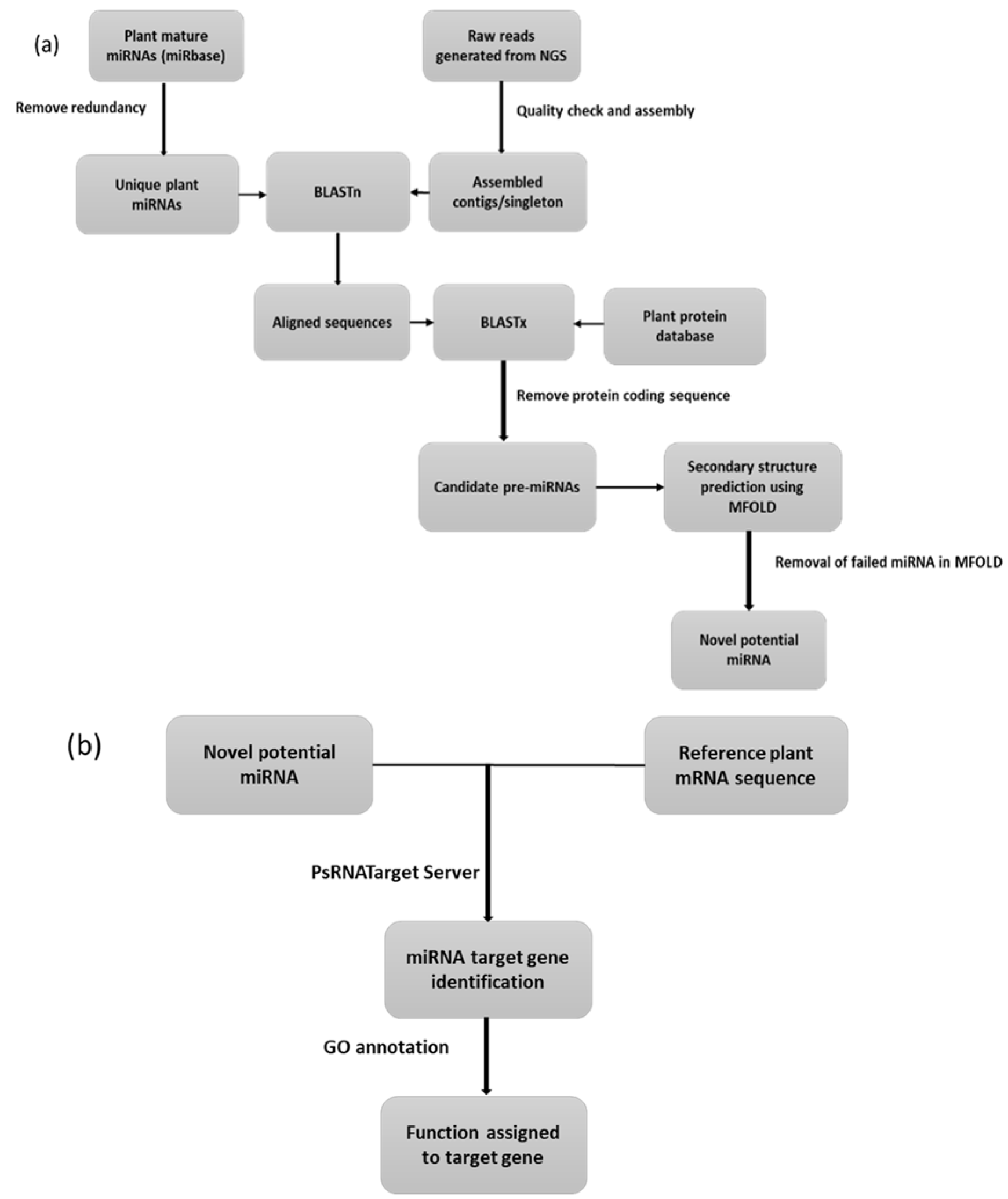

Figure 2. Workflow for in silico mining of (a) plant miRNA, and (b) target genes from transcriptomic data generated using next generation sequencing (NGS). The flowchart is modified from Panda et al. (2014) [62]. 


\section{Functional Role of miRNAs in Plant Stresses}

Abiotic and biotic stresses have become the major factors in limiting crop productivity. Many studies suggest the important role of plant miRNAs in response to abiotic and biotic stresses $[3,4,19,20,66,67]$. Several miRNAs show differential expression under different environmental conditions; however, these expression changes depend on many factors such as the type and magnitude of stress, plant species, and miRNA involved [4]. Nevertheless, an appropriate genetic engineering approach needs to be applied to validate the expression and molecular mechanism underlying the response of plant miRNA to stresses.

\subsection{Role of Plant miRNAs in Abiotic Stress}

Plants, during their entire life cycle, encounter several abiotic stresses including drought, salinity, heavy metals, oxidative stress, and extreme temperatures. Abiotic stresses pose serious deleterious implications on plant growth and development caused due to the oxidative damage of lipids, protein, and DNA, as well as the accumulation or abnormal increase in the levels of molecules such as osmolytes (during drought and salinity stress) or reactive oxygen species (in case of oxidative stress) within the plant $[24,68,69]$. Over the years, miRNA has emerged as an important candidate in managing plants' responses to abiotic stress $[4,12,39]$. The first report that provided a direct link between the levels of miRNA and plant stress responses was the miR398 that targets two closely related $\mathrm{Cu} / \mathrm{Zn}$ superoxide dismutase coding genes (CSD1 and CSD2) and miR395 and miR399, which target the sulfate transporter (AST68) and the phosphate transporter (PHO1), respectively [70]. Later, more and more evidence accumulated showing the aberrant expression of miRNA under abiotic stress in various crop plants, including wheat, maize, rice, cotton, barley, and many others. Table 1 lists the major findings regarding role of miRNA in response to abiotic and biotic stresses in various crop plants. Manipulating a single miRNA in plants significantly changes the stress tolerance capability; thus, among various miRNAs, some are identified as promising targets for developing transgenics with improved abiotic stress tolerance $[4,39]$. For instance, overexpression of miR169 leads to higher tolerance to water deficiency during early plant development in tomatoes [71]. The transgenic tomatoes developed the ability to retain more water inside the cell and require less water from the soil [71]. The study further showed that overexpression of miR169 causes a reduction in the stomatal aperture index and stomatal conductance thereby significantly reducing the transpiration rate in transgenic tomato. Subsequently, overexpression of miR169, the largest and most conserved family of miRNAs, was validated under different abiotic stresses in several other plant species, including some crops also. For example, overexpression of miR169 led to enhanced tolerance capacity against drought and salinity in Agrotis stolonifera (bentgrass) [72]. Moreover, overexpression of miR169 increases cold stress tolerance in rice [73]. In Arabidopsis, overexpression of miR169 makes the plant hypersensitive to nitrogen starvation [74].

The role of other miRNA families viz. miR156, miR159, miR319, miR393, miR394, miR395, miR395, miR396, miR402, miR417, and miR828, in abiotic stress response has also been validated following a transgenic approach in several plant species $[4,24]$. For example, overexpression of miR156 and miR159 enhanced the heat stress tolerance in Arabidopsis [75] and rice [76], respectively. Similarly, manipulation of miR319 enhances the multiple stress tolerance ability in plants. Over-expressed miR319 increases chilling tolerance in rice [73] as well as drought tolerance in bentgrass [72]. The miR393 and miR396 mediate multiple stresses such as drought, heat, and salinity tolerance capacity in transgenic rice [77-79]. Moreover, overexpressed miR828 helps sweet potato to tolerate oxidative stress by exhibiting increased lignin biosynthesis and hydrogen peroxide production [80]. There is a long list of crop plants, which have been genetically engineered to improve abiotic stress tolerance using overexpression or knock out of particular miRNA. The evidence discussed above clearly demonstrate that miRNAs have become the new target for crop improvement and in developing abiotic stress tolerance in crop varieties. 


\subsection{Role of Plant miRNA in Biotic Stress}

Like abiotic stresses, biotic stresses also adversely affect crop productivity. Several studies reported differential expression of miRNAs and their target genes in crop plants during the attack of insects, fungi, bacteria, viruses, and nematodes $[19,20,66]$. During evolution, plants developed several sophisticated mechanisms to fight against biotic agents. The regulation of gene expression and networking systems via miRNA is one such mechanism, which enhances the ability of plants to fight against various pathogens. Several NGS studies conducted in biotic stress environments allowed the identification of miRNAs. For instance, strip virus infection in rice downregulated the expression of miR160, miR166, miR171, and miR396 families [67]. Some of these miRNAs were further employed in genetic engineering to develop biotic stress tolerance in crops. For example, overexpression of miR396 develops more tolerance against fungal infection in transgenic Medicago truncatula as compared to wild type plant [67]. In another example, an Arabidopsis mutant repressed for miR159 showed increased tolerance to root knot nematodes [66]. Other miRNA families that have been exploited in genetic engineering approaches against biotic stress include miR160, miR398, miR393, and miR397 in rice [81,82], miR482 in tomato [83], miR396 in tobacco [84], and miR171 in Medicago truncatula [85].

Table 1. List of studies on the functional role of different miRNA/miRNA families in the regulation of abiotic and biotic tresses in major crop species (List updated January 2011-December 2020).

\begin{tabular}{|c|c|c|c|}
\hline Crop & MicroRNAs & Stress Responses & Reference \\
\hline \multirow{3}{*}{ Alfalfa (Medicago sativa) } & multiple miRNAs & Drought stress & [86] \\
\hline & $\begin{array}{l}\mathrm{miR} 3512, \mathrm{miR} 3630, \mathrm{miR} 5213, \mathrm{miR} 5294, \mathrm{miR} 5368 \\
\text { and miR6173 }\end{array}$ & Drought stress & [87] \\
\hline & miR156 & Heat stress & [88] \\
\hline Apple (Malus sylvestris) & multiple miRNAs & Drought stress & [89] \\
\hline \multirow[t]{5}{*}{ Barley (Hordeum L.) } & multiple miRNAs & Drought stress & [90] \\
\hline & Hv-miR827 & Drought stress & [91] \\
\hline & $\begin{array}{l}\text { Ath-miR169b, Osa-miR1432, } \\
\text { Hv-miRx5, Hv-miR166b/c }\end{array}$ & Drought stress & [92] \\
\hline & multiple miRNAs & Drought stress & [93] \\
\hline & multiple miRNAs & Salt stress & [94] \\
\hline \multirow{2}{*}{ Bean (Phaseolus vulgaris) } & multiple miRNAs & Drought stress & [95] \\
\hline & miR399 & Phosphorus deficiency & [96] \\
\hline Brassica (Brassica juncea) & multiple miRNAs & Abiotic stresses & [97] \\
\hline \multirow{3}{*}{ Brassica (Brassica napus) } & miR1885 & Immune response & [98] \\
\hline & miR397a, miR397b and miR6034 & Various stresses & [99] \\
\hline & multiple miRNAs & Drought and salt stress & [100] \\
\hline Broccoli (Brassica oleracea) & multiple miRNAs & Heat stress & [101] \\
\hline \multirow{2}{*}{ Cabbage (Brassica L.) } & multiple miRNAs & Heat and drought stress & [102] \\
\hline & multiple miRNAs & Turnip Mosaic Virus infection & [103] \\
\hline Cassava (Manihot esculenta) & miR160, miR393 & Anthracnose disease & [104] \\
\hline Celery (Apium graveolens) & multiple miRNAs & Heat and cold stress & [105] \\
\hline \multirow[b]{2}{*}{ Chickpea (Cicer arietinum) } & multiple miRNAs & Ascochyta blight disease & [106] \\
\hline & $\begin{array}{l}\text { multiple miRNAs including miR5213, miR5232, } \\
\text { miR2111 and miR2118 }\end{array}$ & Wilt and salt stress & [107] \\
\hline
\end{tabular}


Table 1. Cont.

\begin{tabular}{|c|c|c|c|}
\hline Crop & MicroRNAs & Stress Responses & Reference \\
\hline \multirow{8}{*}{ Cotton (Gossypium L.) } & miR414 & Salinity stress & [108] \\
\hline & ghr-miR399 and ghr-156e & Salt stress & [94] \\
\hline & $\operatorname{miR} 319$ & Abiotic stress signaling & [109] \\
\hline & ghr-miR5272a & Immune response & [110] \\
\hline & multiple miRNAs & Salt stress & [111] \\
\hline & multiple miRNAs & High temperature & [112] \\
\hline & multiple miRNAs & Low and high temperature stress & [113] \\
\hline & $\begin{array}{l}\mathrm{miR156a/d/e,} \mathrm{miR167a,} \mathrm{miR169,} \mathrm{miR397a/b,} \mathrm{miR399a,} \\
\text { miR535a/b, miR827b, }\end{array}$ & Salt stress & [114] \\
\hline Cowpea (Vigna unguiculata) & multiple miRNAs & Drought stress & [115] \\
\hline Date Palm (Phoenix dactylifera) & multiple miRNAs & Salinity stress & [116] \\
\hline Flax ( Linum usitatissimum) & miR319, miR390, and miR393 & Aluminum stress & [117] \\
\hline \multirow{2}{*}{ Foxtail Millet (Setaria italica) } & multiple miRNAs & Drought stress & [118] \\
\hline & multiple miRNAs & Dehydration stress & [119] \\
\hline $\begin{array}{l}\text { Java waterdropwort } \\
\text { (Oenanthe javanica) }\end{array}$ & multiple miRNAs & Various abiotic stress & [120] \\
\hline \multirow{10}{*}{ Maize (Zea mays) } & multiple miRNAs & Chilling stress & [121] \\
\hline & multiple miRNAs & Heat stress & [122] \\
\hline & multiple miRNAs & Nitrogen stress & [123] \\
\hline & multiple miRNAs & Drought stress & [82] \\
\hline & multiple miRNAs & Cadmium stress & [124] \\
\hline & multiple miRNAs & Phosphate deficiency & [125] \\
\hline & multiple miRNAs & Water logging & [126] \\
\hline & multiple miRNAs & Nitrogen deficiency & [127] \\
\hline & multiple miRNAs & Short term water logging & [128] \\
\hline & $\begin{array}{l}\text { miR160, miR164, miR167, miR168, miR169, miR172, } \\
\text { miR169, miR395, miR397, miR398, miR399, miR408, } \\
\text { miR528, miR827 }\end{array}$ & Low nitrate availability & [129] \\
\hline Peach (Prunus persica) & multiple miRNAs & UVB radiations response & [130] \\
\hline Pear (Pyrus pyrifolia) & multiple miRNAs & $\begin{array}{l}\text { Apple stem grooving virus } \\
\text { infection and high temperature }\end{array}$ & [131] \\
\hline \multirow{3}{*}{ Potato (Solanum tuberosum) } & multiple miRNAs & Nitrogen stress & [132] \\
\hline & Stu-mi164 & Osmotic stress & [133] \\
\hline & $\begin{array}{l}\text { miR172, miR396a, miR396c, miR4233, miR2673, } \\
\text { miR6461 }\end{array}$ & Drought stress & [134] \\
\hline \multirow{5}{*}{ Radish (Raphanus sativus) } & $\begin{array}{l}\text { ath-miR159b-3p, athmiR159c, ath-miR398a-3p, } \\
\text { athmiR398b-3p, ath-miR165a-5p, ath-miR169g-3p, } \\
\text { novel_86, novel_107, novel_21, ath-miR171b-3p }\end{array}$ & Heat stress & [135] \\
\hline & multiple miRNAs & Cadmium stress & [136] \\
\hline & multiple miRNAs & Chromium stress & [137] \\
\hline & multiple miRNAs & Salt stress & [138] \\
\hline & multiple miRNAs & Cadmium stress & [139] \\
\hline
\end{tabular}


Table 1. Cont.

\begin{tabular}{|c|c|c|c|}
\hline Crop & MicroRNAs & Stress Responses & Reference \\
\hline \multirow{13}{*}{ Rice (Oryza sativa) } & miR408, miR528 & Cadmium stress & {$[140]$} \\
\hline & multiple miRNAs & Arsenic stress & {$[141]$} \\
\hline & multiple miRNAs & High temperature and salt stress & [142] \\
\hline & multiple miRNAs & Cold stress & {$[143]$} \\
\hline & miR169, osa-miR444a.4-3p & Nitrogen starvation & {$[144]$} \\
\hline & miR529a & Oxidative stress & {$[145]$} \\
\hline & miR393, miR390 & Multiple stress & {$[146]$} \\
\hline & Osa-miR820 & Salt stress & {$[147]$} \\
\hline & multiple miRNAs & Phosphate Starvation & {$[148]$} \\
\hline & miR399, miR530 & Nitrogen starvation & [149] \\
\hline & $\begin{array}{l}\text { miR156, miR164, } \operatorname{miR} 167, \operatorname{miR} 168, \operatorname{miR} 528, \operatorname{miR} 820, \\
\text { miR821, miR1318 }\end{array}$ & Low-nitrogen stress & [150] \\
\hline & multiple miRNAs & Abiotic stress & [151] \\
\hline & osa-miR414, osa-miR164e, osa-miR408 & Salt stress & {$[152]$} \\
\hline Soybean (Glycine max) & multiple miRNAs & Water deficit & {$[153]$} \\
\hline \multirow{5}{*}{ Sugarcane (Saccharum L.) } & multiple miRNAs & Water-deficit stress & {$[154]$} \\
\hline & multiple miRNAs & Low temperature stress & {$[155]$} \\
\hline & multiple miRNAs & Waterlogging condition & {$[156]$} \\
\hline & multiple miRNAs & Drought stress & {$[157]$} \\
\hline & multiple miRNAs & Drought stress & {$[158]$} \\
\hline \multirow{2}{*}{ Sweet Potato (Ipomoea batatas) } & multiple miRNAs & Drought and $\mathrm{CO}_{2}$ stress & [159] \\
\hline & multiple miRNAs & Salt stress & {$[160]$} \\
\hline \multirow{2}{*}{ Switchgrass (Panicum virgatum) } & multiple miRNAs & Drought and heat stress & {$[161]$} \\
\hline & multiple miRNAs & Salt stress & {$[162]$} \\
\hline Tobacco (Nicotiana tabacum) & multiple miRNAs & Salt and alkali stress & {$[163]$} \\
\hline \multirow{2}{*}{ Tomato (Solanum lycopersicum) } & multiple miRNAs & Drought and heat stress & {$[164]$} \\
\hline & multiple miRNAs & Drought stress & {$[165]$} \\
\hline Turnip (Brassica rapa) & $\begin{array}{l}\text { miR166h-3p-1, miR398b-3p, miR398b-3p-1, miR408d, } \\
\text { miR156a-5p, miR396h, miR845a-1, miR166u, } \\
\text { Bra-novel-miR3153-5p and Bra-novel-miR3172-5p }\end{array}$ & Cold stress & {$[166]$} \\
\hline \multirow{9}{*}{ Wheat (Triticum aestivum) } & multiple miRNAs & $\begin{array}{l}\text { Reactive oxygen species } \\
\text { (ROS) response }\end{array}$ & {$[167]$} \\
\hline & multiple miRNAs & Water deficit and heat stress & {$[168]$} \\
\hline & TaemiR408 & $\begin{array}{l}\text { Phosphate deprivation and } \\
\text { salt stress }\end{array}$ & {$[169]$} \\
\hline & TamiR1139 & Phosphate starvation & {$[170]$} \\
\hline & multiple miRNAs & Cold stress & {$[171]$} \\
\hline & multiple miRNAs & Drought stress & {$[172]$} \\
\hline & $\begin{array}{l}\text { miR159, } \operatorname{miR} 160, \operatorname{miR} 166, \operatorname{miR} 169, \operatorname{miR} 172, \operatorname{miR} 395 \\
\text { miR396, } \\
\text { miR408, } \operatorname{miR} 472, \operatorname{miR} 477, \operatorname{miR} 482, \operatorname{miR} 1858,\end{array}$ & Drought stress & {$[173]$} \\
\hline & multiple miRNAs including miR159, miR393, miR398 & Cold, wound, and salt stress & {$[174]$} \\
\hline & Tae-miR408 & $\begin{array}{l}\text { Salinity, cupric metal, and stripe } \\
\text { rust stress }\end{array}$ & {$[175]$} \\
\hline
\end{tabular}

\section{Current miRNA-Based Strategies for Crop Improvement}

Several miRNA-based strategies are currently being exploited in the field of crop improvement. Genetic tools such as high throughput sequencing, quantitative-real time 
polymerase chain reaction (qRT-PCR), and other gene expression analytic tools are used to elucidate the functional role of plant miRNAs. However, these tools do not provide any direct evidence of gene functionality but are utilized for the identification and revalidation of the related function of plant miRNAs. Another strategy utilized for exploring miRNA function in crop improvement is the traditional transgenic approach. Earlier, many studies recorded the overexpression or repression changes in the miRNA and related gene function in transgenic plants. However, since a single miRNA may regulate several genes, its overexpression or repression sometimes produces undesirable phenotypic changes also. Furthermore, over-abundance of miRNA may alter the expression of respective target genes having different roles in plant development, resulting in a deleterious effect on the host plant. Therefore, the implementation of target specific genetic engineering is required for miRNA-based strategies of crop improvement. In the recent past, target specific approaches such as the use of specific promoters rather than whole genes have enabled miRNA-based strategies to be more precise to introduce desirable traits in crop plants. The various miRNA-based strategies currently utilizing for crop improvement is presented in Figure 3.

\subsection{Traditional Transgenic Strategy}

Earlier plant science researchers overexpressed plant miRNA in several crop and model plants to study the role of miRNA and its related gene function. However, the small size of plant miRNA and the requirement of the exact miRNA sequence makes it rather difficult to manipulate. Therefore, following an alternative approach, plant scientists started transferring the long pri-miRNA sequence instead of mature miRNA. This strategy helped in expressing direct mature miRNA rather than manipulating the MIR gene. Further, pre-miRNA from model plant species can be utilized easily for crop plants with unknown genetic information [39]. For instance, the miR156 gene from Arabidopsis can be transferred to eggplants with unknown genetic information to study the function of this miRNA [39].

\subsection{Artificial miRNA (amiRNA) Strategy}

To overcome the problem of affecting non-target gene in the plant miRNA traditional transgenic approach, alternative artificial miRNA (amiRNA) was developed $[176,177]$. The amiRNA approach produces miRNAs and specifically silences the target genes without interfering with the function of other genes [177]. In the amiRNA approach, the gene sequence can be utilized to construct mature amiRNA having the conserved stem-loop structure like original pre-miRNA and complementary sequence to target mRNA. The artificial miRNA:miRNA* duplex can be inserted into the transgenic plant directly in the stem-loop structure to target specific mRNA. In this way, amiRNA can be transferred to target mRNA with high specificity without effecting a non-target gene function as compared to the traditional transgenic approach. An amiRNA has also been utilized in many studies, including knocking out genes for phytopathogens in Arabidopsis and tobacco [178-181].

\subsection{Short Tandem Target MIMIC (STTM) Strategy}

Like overexpression of plant miRNA using the amiRNA approach, another artificial technique called short tandem target MIMIC (STTM) that modulates the accumulation of miRNA and controls related biological processes was developed. The SSTM, by inhibiting specific miRNA activity, has been employed in several plant species $[182,183]$. In the STTM strategy, either engineered long non-coding RNA (lncRNA) or circular RNA (circRNA), also called miRNA recognition elements (MRE) with high sequence similarity with target miRNA is transferred to the transgenic plant [184]. This engineered lncRNA or circRNA has two or more conserved binding sites with target miRNA and minor differences in sequences at the cleavage site. This prevents its miRNA cleavage, which remains hybridized but biologically inactive $[184,185]$. Recently, several MIR genes have been targeted by the STTM approach in crop plants to explore the function of miRNAs $[83,92,93]$. For example, 
the function of 35 miRNA families related to important agronomical traits has been studied using STTM strategy in rice [183]. Like STTM, another artificial transcript called miRNA SPONGES having multiple miRNA binding sites, was also engineered in some plant species $[184,186]$. These miRNA SPONGES are sometimes utilized to inhibit the function of the whole plant miRNA family $[83,183]$.

\subsection{Clustered Regularly Interspaced Short Palindromic Repeats/CRISPR Associated Gene 9 (CRISPR/Cas 9) Approach}

Plant miRNAs have more than one member in a family, and each member plays an important function in a group or individually. The above-mentioned miRNA-based strategies target miRNA without differentiating among members of the miRNA family. To elucidate the role of individual miRNA from a miRNA family, recently developed clustered regularly interspaced short palindromic repeats/CRISPR associated gene 9 (CRISPR/Cas 9) $[187,188]$ proved to be a powerful tool. In protein coding genes, CRISPR/Cas 9 deletes a few nucleotides adjacent to the protospacer motif (PAM) sequence resulting in a frameshift and finally gene silencing. However, the removal of a few nucleotides in miRNA does not efficiently silence MIR genes, which makes it challenging to apply CRISPR/Cas 9. Therefore, only a small number of studies have been reported for the successful implementation of the CRISPR/Cas 9 approach for knocking out miRNA genes [189,190]. For example, miR1514 and miR1509 have successfully been targeted in soybean by CRISPR/Cas 9 [191]. The miRNA1514 and miRNA1509 were targeted using biolistic delivery of a CRISPR/Cas 9 vector for the transient expression [192]. Likewise, in rice, a specific mutation has been induced in miRNA156 recognition sites of the ipa1 gene using CRISPR/Cas 9 to improve the number of traits related to plant architecture [102]. In another report, mono-allelic and bi-allelic mutations in several miRNA genes of the T0 line of rice have successfully been incorporated using CRISPR/Cas 9, resulting in the loss of function of miRNA [193]. Though the genome editing approach has been successfully implemented in some miRNA studies, there are still some gaps needing improvement to thoroughly amend CRISPR/Cas 9 technology for miRNA-based crop improvement.

(a) Traditional transgenic strategy

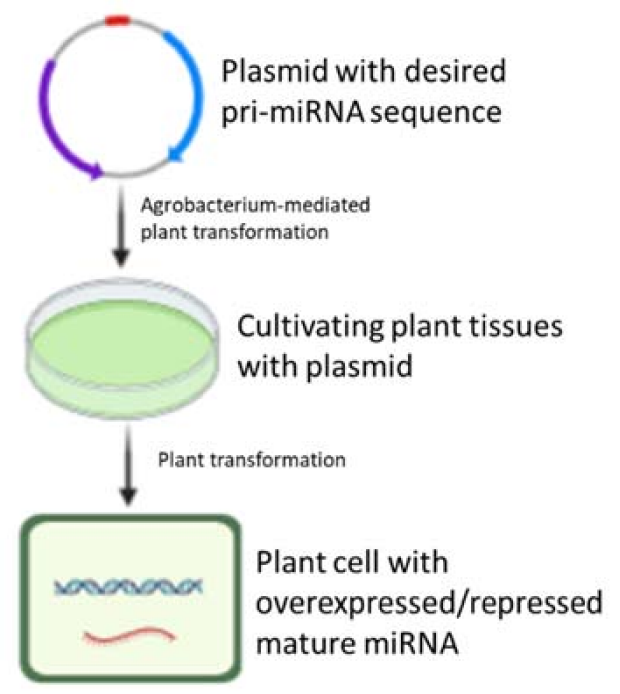

\section{(b) Artificial miRNA (amiRNA) strategy}

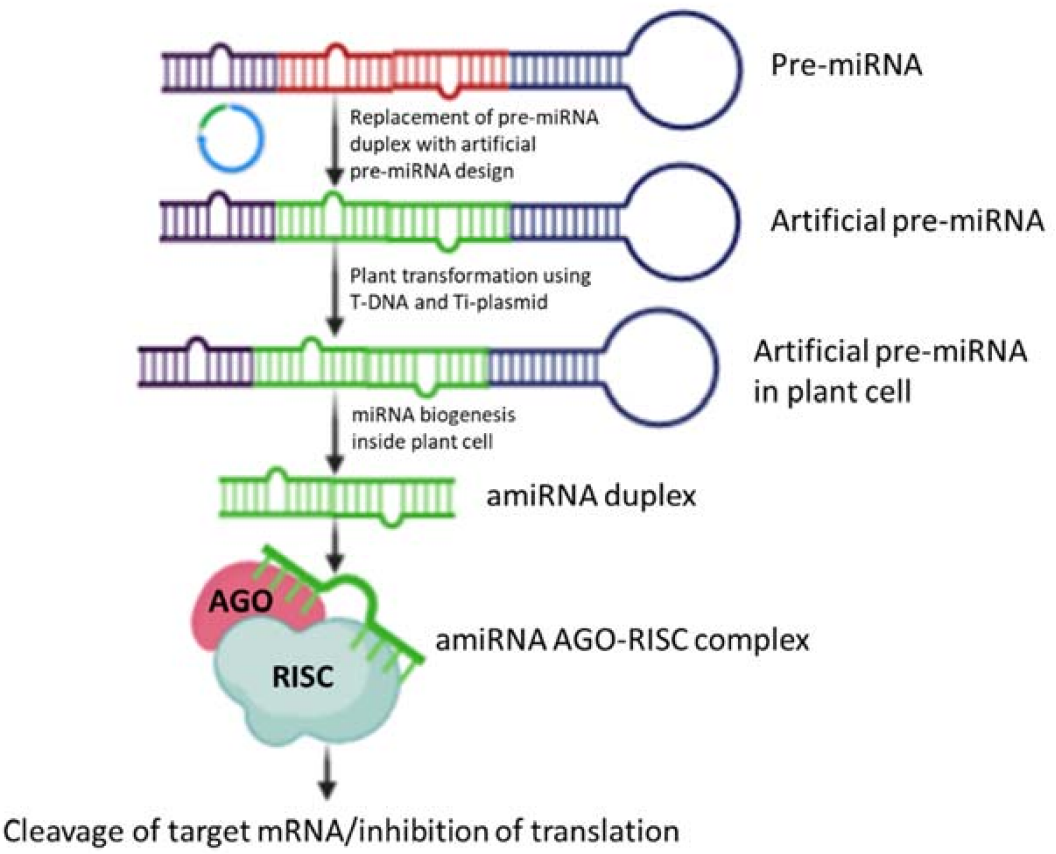

Figure 3. Cont. 
(c) Target MIMIC strategy

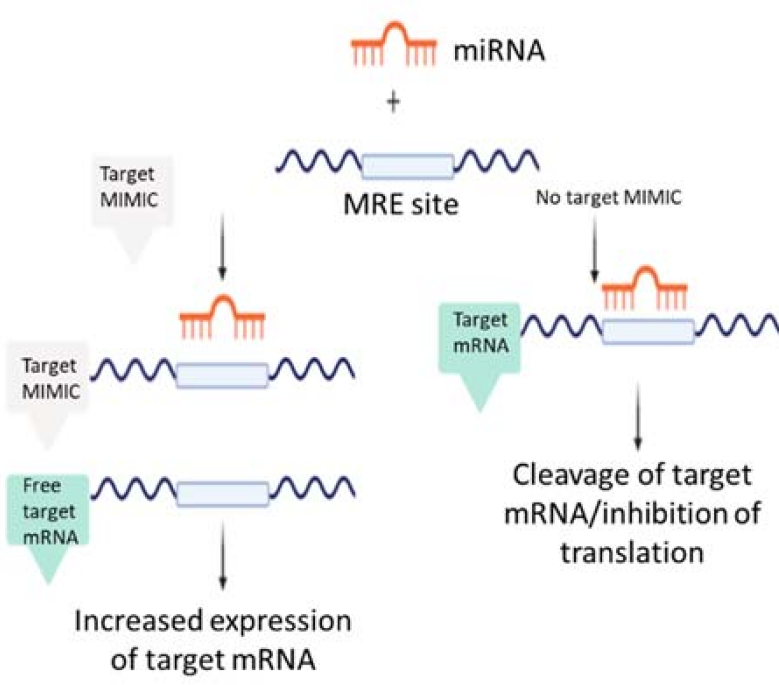

(d) CRISPR/Cas9 strategy

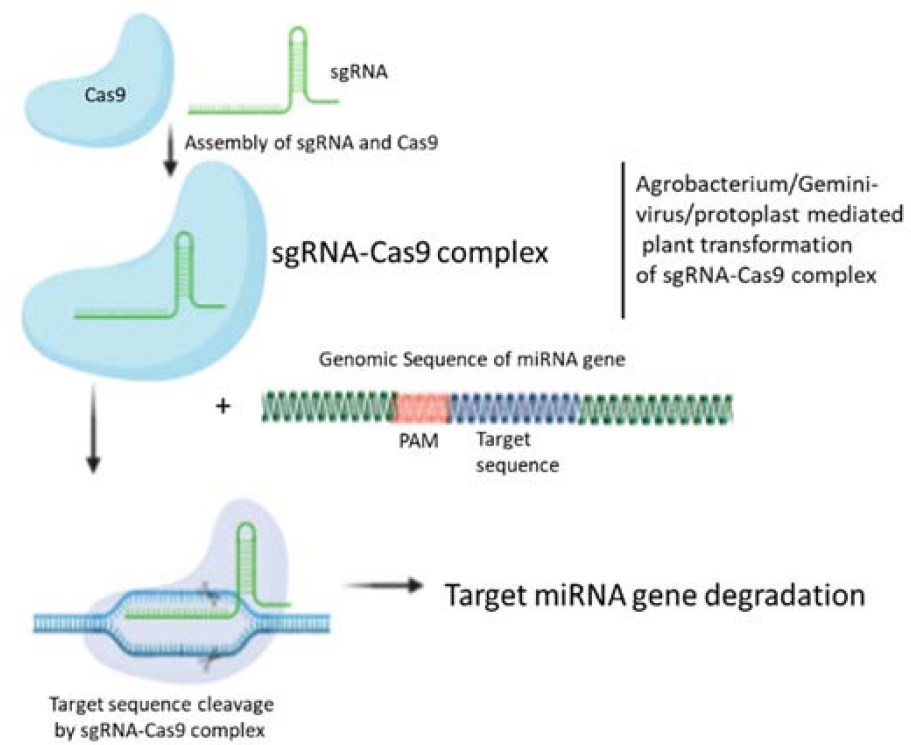

Figure 3. Overview of miRNA-based strategies for crop improvement. Illustrating (a) the traditional transgenic approach targeting directly primary-miRNA (pri-miRNA) in plants; (b) the artificial miRNA (amiRNA) strategy to enhance or repress miRNA expression in plants (Sablok et al., 2011). The amiRNA is designed to have a complementary sequence to the target mRNA and stem-loop structure like the original miRNA. The amiRNA then transfers into the plant cell using traditional transformation techniques, where its biogenesis occurs like original miRNA. Finally, amiRNA targets the mRNA without affecting non-target genes; (c) target MIMIC strategy where target MIMIC instead of target mRNA is recognized by miRNA; (MRE site: miRNA recognition site) [194]; (d) miRNA-targeting CRISPR/Cas9 approach to manipulate the miRNA gene using sgRNA-Cas9 complex. CRISPR/Cas9 techniques based on two components, (i) sgRNA: single guide RNA, and (ii) Cas9 endonucleases. The sgRNA consists of a 20-nt-long spacer sequence which is highly specific to target DNA having a 5'-NGG-3'PAM (protospacer adjacent motif). The Cas9 vector construct and sgRNA complex transfer into a plant cell using a transformation technique. In the plant cell, sgRNA-Cas9 complex target and cleave the DNA and degrade the targeted gene. This figure was created with the BioRender app (https://app.biorender.com/; accessed on 30 April 2020).

\section{Conclusions}

In addition to the fundamental role of gene silencing, plant miRNAs play diverse roles in almost all biological (molecular) networks. The potential of plant miRNAs in regulating stress-responsive genes makes them a suitable candidate for developing stresstolerant crop varieties. A deeper understanding of the molecular mechanism regulated by miRNA in the complex molecular networking systems would enable agricultural scientists to manipulate specific agronomical traits in crops. However, the regulation of multiple genes and networks by single miRNA in plants makes the selection of candidate miRNA to target specific agronomically important trait challenging for the scientists. For such traits, efficient tools are required to decipher pri-miRNA-mediated regulatory networks. Undoubtedly, miRNA-based approaches have huge potential for crop improvement to motivate future inter-disciplinary collaborations between scientists of different expertise. For example, a successful miRNA-mediated genome editing effort requires active collaborative efforts from molecular biologists, geneticists, genome editors, miRNA scientists, and plant breeders. Furthermore, appropriate laboratory experiments and confined field trials are required before realizing the actual potential of miRNA-based genome editing in the field of agriculture. Nevertheless, it is also pertinent to be aware of unwanted side effects arising while using genetic modification approaches using miRNAs in the future. 
Author Contributions: Conceptualization and Finalization of the Review, P.C.S.; Original Draft Preparation of the Review, S.C.; Editing, A.G. All authors have read and agreed to the published version of the manuscript.

Funding: This research received no external funding.

Institutional Review Board Statement: Not applicable.

Informed Consent Statement: Not applicable.

Data Availability Statement: Not applicable.

Conflicts of Interest: The authors declare no conflict of interest.

\section{References}

1. Singhal, P.; Jan, A.T.; Azam, M.; Haq, Q.M.R. Plant abiotic stress: A prospective strategy of exploiting promoters as alternative to overcome the escalating burden. Front. Life Sci. 2015, 9, 52-63. [CrossRef]

2. Roberts, D.P.; Mattoo, A.K. Sustainable Agriculture-Enhancing Environmental Benefits, Food Nutritional Quality and Building Crop Resilience to Abiotic and Biotic Stresses. Agriculture 2018, 8, 8. [CrossRef]

3. Zhang, B.; Wang, Q. MicroRNA-based biotechnology for plant improvement. J. Cell. Physiol. 2015, 230, 1-15. [CrossRef] [PubMed]

4. Zhang, B. MicroRNA: A new target for improving plant tolerance to abiotic stress. J. Exp. Bot. 2015, 66, 1749-1761. [CrossRef]

5. Djami-Tchatchou, A.T.; Sanan-Mishra, N.; Ntushelo, K.; Dubery, I.A. Functional Roles of microRNAs in Agronomically Important Plants-Potential as Targets for Crop Improvement and Protection. Front. Plant Sci. 2017, 8, 378. [CrossRef]

6. Xu, J.; Hou, Q.-M.; Khare, T.; Verma, S.K.; Kumar, V. Exploring miRNAs for developing climate-resilient crops: A perspective review. Sci. Total Environ. 2019, 653, 91-104. [CrossRef]

7. Jones-Rhoades, M.W.; Bartel, D.P.; Bartel, B. MicroRNAs and their regulatory roles in plants. Annu. Rev. Plant Biol. 2006, 57, 19-53. [CrossRef]

8. Chen, X. Small RNAs and Their Roles in Plant Development. Annu. Rev. Cell Dev. Biol. 2009, 25, 21-44. [CrossRef]

9. Reis, R.S.; Eamens, A.L.; Waterhouse, P.M. Missing Pieces in the Puzzle of Plant MicroRNAs. Trends Plant Sci. 2015, 20, 721-728. [CrossRef]

10. Cuperus, J.T.; Fahlgren, N.; Carrington, J.C. Evolution and Functional Diversification of MIRNA Genes. Plant Cell 2011, 23, 431-442. [CrossRef]

11. Khraiwesh, B.; Zhu, J.-K.; Zhu, J. Role of miRNAs and siRNAs in biotic and abiotic stress responses of plants. Biochim. Biophys. Acta BBA Bioenerg. 2012, 1819, 137-148. [CrossRef]

12. Sunkar, R.; Li, Y.-F.; Jagadeeswaran, G. Functions of microRNAs in plant stress responses. Trends Plant Sci. 2012, 17, 196-203. [CrossRef] [PubMed]

13. Bouba, I.; Kang, Q.; Luan, Y.-S.; Meng, J. Predicting miRNA-lncRNA interactions and recognizing their regulatory roles in stress response of plants. Math. Biosci. 2019, 312, 67-76. [CrossRef] [PubMed]

14. Song, X.; Li, Y.; Cao, X.; Qi, Y. MicroRNAs and Their Regulatory Roles in Plant-Environment Interactions. Annu. Rev. Plant Biol. 2019, 70, 489-525. [CrossRef]

15. Fouracre, J.P.; Poethig, R.S. The role of small RNAs in vegetative shoot development. Curr. Opin. Plant Biol. $2016,29,64-72$. [CrossRef] [PubMed]

16. Li, C.; Zhang, B. MicroRNAs in Control of Plant Development. J. Cell. Physiol. 2016, 231, 303-313. [CrossRef]

17. Xie, F.; Jones, D.C.; Wang, Q.; Sun, R.; Zhang, B. Small RNA sequencing identifies miRNA roles in ovule and fibre development. Plant Biotechnol. J. 2015, 13, 355-369. [CrossRef]

18. Smoczynska, A.; Szweykowska-Kulinska, Z. MicroRNA-mediated regulation of flower development in grasses. Acta Biochim. Pol. 2016, 63, 687-692. [CrossRef] [PubMed]

19. Du, P.; Wu, J.; Zhang, J.; Zhao, S.; Zheng, H.; Gao, G.; Wei, L.; Li, Y. Viral Infection Induces Expression of Novel Phased MicroRNAs from Conserved Cellular MicroRNA Precursors. PLOS Pathog. 2011, 7, e1002176. [CrossRef]

20. Salvador-Guirao, R.; Baldrich, P.; Weigel, D.; Rubio-Somoza, I.; Segundo, B.S. The MicroRNA miR773 Is Involved in the Arabidopsis Immune Response to Fungal Pathogens. Mol. Plant Microb. Interact. 2018, 31, 249-259. [CrossRef]

21. Kumar, R. Role of MicroRNAs in Biotic and Abiotic Stress Responses in Crop Plants. Appl. Biochem. Biotechnol. 2014, 174, 93-115. [CrossRef] [PubMed]

22. Noman, A.; Fahad, S.; Aqeel, M.; Ali, U.; Amanullah; Anwar, S.; Baloch, S.K.; Zainab, M. miRNAs: Major modulators for crop growth and development under abiotic stresses. Biotechnol. Lett. 2017, 39, 685-700. [CrossRef] [PubMed]

23. Shriram, V.; Kumar, V.; Devarumath, R.M.; Khare, T.S.; Wani, S.H. MicroRNAs as Potential Targets for Abiotic Stress Tolerance in Plants. Front. Plant Sci. 2016, 7, 817. [CrossRef]

24. Basso, M.F.; Ferreira, P.C.G.; Kobayashi, A.K.; Harmon, F.G.; Nepomuceno, A.L.; Molinari, H.B.C.; Grossi-De-Sa, M.F. Micro RNA s and new biotechnological tools for its modulation and improving stress tolerance in plants. Plant Biotechnol. J. 2019, 17, 1482-1500. [CrossRef] [PubMed] 
25. Sun, X.; Lin, L.; Sui, N. Regulation mechanism of microRNA in plant response to abiotic stress and breeding. Mol. Biol. Rep. 2019, 46, 1447-1457. [CrossRef] [PubMed]

26. Ma, C.; Burd, S.; Lers, A. miR408is involved in abiotic stress responses in Arabidopsis. Plant J. 2015, 84, 169-187. [CrossRef]

27. Inal, B.; Türktaş, M.; Eren, H.; Ilhan, E.; Okay, S.; Atak, M.; Erayman, M.; Unver, T. Genome-wide fungal stress responsive miRNA expression in wheat. Planta 2014, 240, 1287-1298. [CrossRef]

28. Wu, F.; Shu, J.; Jin, W. Identification and Validation of miRNAs Associated with the Resistance of Maize (Zea mays L.) to Exserohilum turcicum. PLoS ONE 2014, 9, e87251. [CrossRef]

29. Fukudome, A.; Fukuhara, T. Plant dicer-like proteins: Double-stranded RNA-cleaving enzymes for small RNA biogenesis. J. Plant Res. 2017, 130, 33-44. [CrossRef]

30. Bologna, N.G.; Voinnet, O. The Diversity, Biogenesis, and Activities of Endogenous Silencing Small RNAs in Arabidopsis. Annu. Rev. Plant Biol. 2014, 65, 473-503. [CrossRef]

31. Bartel, D.P. MicroRNAs: Genomics, Biogenesis, Mechanism, and Function. Cell 2004, 116, 281-297. [CrossRef]

32. Yu, B.; Yang, Z.; Li, J.; Minakhina, S.; Yang, M.; Padgett, R.W.; Steward, R.; Chen, X. Methylation as a Crucial Step in Plant microRNA Biogenesis. Science 2005, 307, 932-935. [CrossRef] [PubMed]

33. Park, W.; Li, J.; Song, R.; Messing, J.; Chen, X. CARPEL FACTORY, a Dicer Homolog, and HEN1, a Novel Protein, Act in microRNA Metabolism in Arabidopsis thaliana. Curr. Biol. 2002, 12, 1484-1495. [CrossRef]

34. Xie, M.; Zhang, S.; Yu, B. microRNA biogenesis, degradation and activity in plants. Cell. Mol. Life Sci. 2014, 72, 87-99. [CrossRef]

35. Ramachandran, V.; Chen, X. Small RNA metabolism in Arabidopsis. Trends Plant Sci. 2008, 13, 368-374. [CrossRef]

36. Baumberger, N.; Baulcombe, D.C. Arabidopsis ARGONAUTE1 is an RNA Slicer that selectively recruits microRNAs and short interfering RNAs. Proc. Natl. Acad. Sci. USA 2005, 102, 11928-11933. [CrossRef] [PubMed]

37. Iki, T. Messages on small RNA duplexes in plants. J. Plant Res. 2016, 130, 7-16. [CrossRef]

38. Arribas-Hernández, L.; Marchais, A.; Poulsen, C.; Haase, B.; Hauptmann, J.; Benes, V.; Meister, G.; Brodersen, P. The Slicer Activity of ARGONAUTE1 is Required Specifically for the Phasing, Not Production, of Trans-Acting Short Interfering RNAs in Arabidopsis. Plant Cell 2016, 28, 1563-1580. [CrossRef]

39. Zhang, B.; Unver, T. A critical and speculative review on microRNA technology in crop improvement: Current challenges and future directions. Plant Sci. 2018, 274, 193-200. [CrossRef]

40. Sun, G. MicroRNAs and their diverse functions in plants. Plant Mol. Biol. 2011, 80, 17-36. [CrossRef]

41. Djami-Tchatchou, A.T.; Dubery, I.A. Lipopolysaccharide perception leads to dynamic alterations in the microtranscriptome of Arabidopsis thaliana cells and leaf tissues. BMC Plant Biol. 2015, 15, 79. [CrossRef]

42. Guleria, P.; Mahajan, M.; Bhardwaj, J.; Yadav, S.K. Plant Small RNAs: Biogenesis, Mode of Action and Their Roles in Abiotic Stresses. Genom. Proteom. Bioinform. 2011, 9, 183-199. [CrossRef]

43. Ebert, M.S.; Sharp, P.A. Roles for MicroRNAs in Conferring Robustness to Biological Processes. Cell 2012, 149, 515-524. [CrossRef]

44. Tang, J.; Chu, C. MicroRNAs in crop improvement: Fine-tuners for complex traits. Nat. Plants 2017, 3, 17077. [CrossRef]

45. Llave, C.; Xie, Z.; Kasschau, K.D.; Carrington, J.C. Cleavage of Scarecrow-like mRNA Targets Directed by a Class of Arabidopsis miRNA. Science 2002, 297, 2053-2056. [CrossRef] [PubMed]

46. Ma, X.; Tang, Z.; Qin, J.; Meng, Y. The use of high-throughput sequencing methods for plant microRNA research. RNA Biol. 2015, 12, 709-719. [CrossRef] [PubMed]

47. Xie, F.; Frazier, T.P.; Zhang, B. Identification, characterization and expression analysis of MicroRNAs and their targets in the potato (Solanum tuberosum). Gene 2011, 473, 8-22. [CrossRef]

48. Han, J.; Kong, M.; Xie, H.; Sun, Q.; Nan, Z.; Zhang, Q.; Pan, J. Identification of miRNAs and their targets in wheat (Triticum aestivum L.) by EST analysis. Genet. Mol. Res. 2013, 12, 3793-3805. [CrossRef] [PubMed]

49. Matts, J.; Jagadeeswaran, G.; Roe, B.A.; Sunkar, R. Identification of microRNAs and their targets in switchgrass, a model biofuel plant species. J. Plant Physiol. 2010, 167, 896-904. [CrossRef]

50. Fullwood, M.J.; Wei, C.-L.; Liu, E.T.; Ruan, Y. Next-generation DNA sequencing of paired-end tags (PET) for transcriptome and genome analyses. Genome Res. 2009, 19, 521-532. [CrossRef]

51. Ruan, X.; Ruan, Y. RNA-PET: Full-Length Transcript Analysis Using 5'- and 3'-Paired-End Tag Next-Generation Sequencing. In Tag-Based Next Generation Sequencing; Wiley: Hoboken, NJ, USA, 2012; pp. 73-90.

52. Baker, M. MicroRNA profiling: Separating signal from noise. Nat. Chem. Biol. 2010, 7, 687-692. [CrossRef]

53. Aldridge, S.; Hadfield, J. Introduction to miRNA Profiling Technologies and Cross-Platform Comparison. Methods Mol. Biol. 2011, 822, 19-31. [CrossRef]

54. Zheng, Q.; Ryvkin, P.; Li, F.; Dragomir, I.; Valladares, O.; Yang, J.; Cao, K.; Wang, L.-S.; Gregory, B.D. Genome-Wide DoubleStranded RNA Sequencing Reveals the Functional Significance of Base-Paired RNAs in Arabidopsis. PLoS Genet. 2010, 6, e1001141. [CrossRef]

55. Addo-Quaye, C.; Eshoo, T.W.; Bartel, D.P.; Axtell, M.J. Endogenous siRNA and miRNA Targets Identified by Sequencing of the Arabidopsis Degradome. Curr. Biol. 2008, 18, 758-762. [CrossRef]

56. Li, Y.-F.; Zheng, Y.; Addo-Quaye, C.; Zhang, L.; Saini, A.; Jagadeeswaran, G.; Axtell, M.J.; Zhang, W.; Sunkar, R. Transcriptomewide identification of microRNA targets in rice. Plant J. 2010, 62, 742-759. [CrossRef]

57. Griffiths-Jones, S.; Grocock, R.J.; Van Dongen, S.; Bateman, A.; Enright, A.J. miRBase: microRNA sequences, targets and gene nomenclature. Nucleic Acids Res. 2006, 34, D140-D144. [CrossRef] [PubMed] 
58. Kozomara, A.; Birgaoanu, M.; Griffiths-Jones, S. miRBase: From microRNA sequences to function. Nucleic Acids Res. 2019, 47, D155-D162. [CrossRef] [PubMed]

59. Zhang, Z.; Yu, J.; Li, D.; Zhang, Z.; Liu, F.; Zhou, X.; Wang, T.; Ling, Y.; Su, Z. PMRD: Plant microRNA database. Nucleic Acids Res. 2009, 38, D806-D813. [CrossRef] [PubMed]

60. Barrett, T.; Wilhite, S.E.; Ledoux, P.; Evangelista, C.; Kim, I.F.; Tomashevsky, M.; Marshall, K.A.; Phillippy, K.H.; Sherman, P.M.; Holko, M.; et al. NCBI GEO: Archive for functional genomics data sets-Update. Nucleic Acids Res. 2013, 41, D991-D995. [CrossRef] [PubMed]

61. Floyd, S.K.; Bowman, J.L. Ancient microRNA target sequences in plants. Nat. Cell Biol. 2004, 428, 485-486. [CrossRef] [PubMed]

62. Panda, D.; Dehury, B.; Sahu, J.; Barooah, M.; Sen, P.; Modi, M.K. Computational identification and characterization of conserved miRNAs and their target genes in garlic (Allium sativum L.) expressed sequence tags. Gene 2014, 537, 333-342. [CrossRef] [PubMed]

63. Bateman, A. UniProt: A worldwide hub of protein knowledge. Nucleic Acids Res. 2019, 47, D506-D515. [CrossRef]

64. Zuker, M. Mfold web server for nucleic acid folding and hybridization prediction. Nucleic Acids Res. 2003, 31, 3406-3415. [CrossRef]

65. Dai, X.; Zhao, P.X. psRNATarget: A plant small RNA target analysis server. Nucleic Acids Res. 2011, 39, W155-W159. [CrossRef]

66. Medina, C.; Da Rocha, M.; Magliano, M.; Ratpopoulo, A.; Revel, B.; Marteu, N.; Magnone, V.; Lebrigand, K.; Cabrera, J.; Barcala, M.; et al. Characterization of microRNAs from Arabidopsis galls highlights a role for miR159 in the plant response to the root-knot nematode Meloidogyne incognita. New Phytol. 2017, 216, 882-896. [CrossRef]

67. Bazin, J.; Khan, G.A.; Combier, J.-P.; Bustos-Sanmamed, P.; Debernardi, J.M.; Rodriguez, R.; Sorin, C.; Palatnik, J.; Hartmann, C.; Crespi, M.; et al. miR396 affects mycorrhization and root meristem activity in the legume Medicago truncatula. Plant J. 2013, 74, 920-934. [CrossRef] [PubMed]

68. Yamaguchi-Shinozaki, K.; Shinozaki, K. Transcriptional regulatory networks in cellular responses and tolerance to dehydration and cold stresses. Annu. Rev. Plant Biol. 2006, 57, 781-803. [CrossRef] [PubMed]

69. Zhu, J.-K. Abiotic Stress Signaling and Responses in Plants. Cell 2016, 167, 313-324. [CrossRef]

70. Sunkar, R.; Zhu, J.-K. Novel and Stress-Regulated MicroRNAs and Other Small RNAs from Arabidopsis. Plant Cell 2004, 16, 2001-2019. [CrossRef]

71. Zhang, X.; Zou, Z.; Gong, P.; Zhang, J.; Ziaf, K.; Li, H.; Xiao, F.; Ye, Z. Over-expression of microRNA169 confers enhanced drought tolerance to tomato. Biotechnol. Lett. 2010, 33, 403-409. [CrossRef]

72. Zhou, M.; Li, D.; Li, Z.; Hu, Q.; Yang, C.; Zhu, L.; Luo, H. Constitutive Expression of a miR319 Gene Alters Plant Development and Enhances Salt and Drought Tolerance in Transgenic Creeping Bentgrass. Plant Physiol. 2013, 161, 1375-1391. [CrossRef] [PubMed]

73. Yang, C.; Li, D.; Mao, D.; Liu, X.; Ji, C.; Li, X.; Zhao, X.; Cheng, Z.; Chen, C.; Zhu, L. Overexpression of microRNA319 impacts leaf morphogenesis and leads to enhanced cold tolerance in rice (Oryza sativa L.). Plant Cell Environ. 2013, 36, $2207-2218$. [CrossRef] [PubMed]

74. Zhao, M.; Ding, H.; Zhu, J.-K.; Zhang, F.; Li, W.-X. Involvement of miR169 in the nitrogen-starvation responses in Arabidopsis. New Phytol. 2011, 190, 906-915. [CrossRef] [PubMed]

75. Stief, A.; Altmann, S.; Hoffmann, K.; Pant, B.D.; Scheible, W.-R.; Bäurle, I. Arabidopsis miR156 Regulates Tolerance to Recurring Environmental Stress through SPL Transcription Factors. Plant Cell 2014, 26, 1792-1807. [CrossRef] [PubMed]

76. Wang, Y.; Sun, F.; Cao, H.; Peng, H.; Ni, Z.; Sun, Q.; Yao, Y. TamiR159 Directed Wheat TaGAMYB Cleavage and Its Involvement in Anther Development and Heat Response. PLoS ONE 2012, 7, e48445. [CrossRef]

77. Gao, P.; Bai, X.; Yang, L.; Lv, D.; Pan, X.; Li, Y.; Cai, H.; Ji, W.; Chen, Q.; Zhu, Y. osa-MIR393: A salinity- and alkaline stress-related microRNA gene. Mol. Biol. Rep. 2011, 38, 237-242. [CrossRef]

78. Gao, P.; Bai, X.; Yang, L.; Lv, D.; Li, Y.; Cai, H.; Ji, W.; Guo, D.; Zhu, Y. Over-expression of osa-MIR396c decreases salt and alkali stress tolerance. Planta 2010, 231, 991-1001. [CrossRef] [PubMed]

79. Zhao, J.; Yuan, S.; Zhou, M.; Yuan, N.; Li, Z.; Hu, Q.; Bethea, F.G.; Liu, H.; Li, S.; Luo, H. Transgenic creeping bentgrass overexpressing Osa-miR393a exhibits altered plant development and improved multiple stress tolerance. Plant Biotechnol. J. 2018, 17, 233-251. [CrossRef]

80. Lin, J.-S.; Lin, C.-C.; Lin, H.-H.; Chen, Y.-C.; Jeng, S.-T. Micro R 828 regulates lignin and H 2 O 2 accumulation in sweet potato on wounding. New Phytol. 2012, 196, 427-440. [CrossRef] [PubMed]

81. Li, Y.; Lu, Y.-G.; Shi, Y.; Wu, L.; Xu, Y.-J.; Huang, F.; Guo, X.-Y.; Zhang, Y.; Fan, J.; Zhao, J.-Q.; et al. Multiple Rice MicroRNAs Are Involved in Immunity against the Blast Fungus Magnaporthe oryzae. Plant Physiol. 2014, 164, 1077-1092. [CrossRef]

82. Li, W.; Jia, Y.; Liu, F.; Wang, F.; Fan, F.; Wang, J.; Zhu, J.; Xu, Y.; Zhong, W.; Yang, J. Integration Analysis of Small RNA and Degradome Sequencing Reveals MicroRNAs Responsive to Dickeya zeae in Resistant Rice. Int. J. Mol. Sci. 2019, $20,222$. [CrossRef] [PubMed]

83. Jiang, N.; Meng, J.; Cui, J.; Sun, G.; Luan, Y. Function identification of miR482b, a negative regulator during tomato resistance to Phytophthora infestans. Hortic. Res. 2018, 5, 1-11. [CrossRef]

84. Chen, L.; Luan, Y.; Zhai, J. Sp-miR396a-5p acts as a stress-responsive genes regulator by conferring tolerance to abiotic stresses and susceptibility to Phytophthora nicotianae infection in transgenic tobacco. Plant Cell Rep. 2015, 34, 2013-2025. [CrossRef] [PubMed]

85. Hofferek, V.; Mendrinna, A.; Gaude, N.; Krajinski, F.; A Devers, E. MiR171h restricts root symbioses and shows like its target NSP2 a complex transcriptional regulation in Medicago truncatula. BMC Plant Biol. 2014, 14, 199. [CrossRef] 
86. Zhao, Y.; Ma, W.; Wei, X.; Long, Y.; Zhao, Y.; Su, M.; Luo, Q. Identification of Exogenous Nitric Oxide-Responsive miRNAs from Alfalfa (Medicago sativa L.) under Drought Stress by High-Throughput Sequencing. Genes 2019, 11, 30. [CrossRef]

87. Li, Y.; Wan, L.; Bi, S.; Wan, X.; Li, Z.; Cao, J.; Tong, Z.; Xu, H.; He, F.; Li, X. Identification of Drought-Responsive MicroRNAs from Roots and Leaves of Alfalfa by High-Throughput Sequencing. Genes 2017, 8, 119. [CrossRef]

88. Matthews, C.; Arshad, M.; Hannoufa, A. Alfalfa response to heat stress is modulated by microRNA156. Physiol. Plant 2018, 165, 830-842. [CrossRef] [PubMed]

89. Niu, C.; Li, H.; Jiang, L.; Yan, M.; Li, C.; Geng, D.; Xie, Y.; Yan, Y.; Shen, X.; Chen, P.; et al. Genome-wide identification of droughtresponsive microRNAs in two sets of Malus from interspecific hybrid progenies. Hortic. Res. 2019, 6, 75. [CrossRef] [PubMed]

90. Qiu, C.-W.; Zhao, J.; Chen, Q.; Wu, F. Genome-wide characterization of drought stress responsive long non-coding RNAs in Tibetan wild barley. Environ. Exp. Bot. 2019, 164, 124-134. [CrossRef]

91. Ferdous, J.; Whitford, R.; Nguyen, M.; Brien, C.; Langridge, P.; Tricker, P.J. Drought-inducible expression of Hv-miR827 enhances drought tolerance in transgenic barley. Funct. Integr. Genom. 2017, 17, 279-292. [CrossRef]

92. Ferdous, J.; Sanchez-Ferrero, J.C.; Langridge, P.; Milne, L.; Chowdhury, J.; Brien, C.; Tricker, P.J. Differential expression of microRNAs and potential targets under drought stress in barley. Plant Cell Environ. 2016, 40, 11-24. [CrossRef]

93. Hackenberg, M.; Gustafson, P.; Langridge, P.; Shi, B. Differential expression of micro RNA s and other small RNA s in barley between water and drought conditions. Plant Biotechnol. J. 2015, 13, 2-13. [CrossRef]

94. Deng, P.; Wang, L.; Cui, L.; Feng, K.; Liu, F.; Du, X.; Tong, W.; Nie, X.; Ji, W.; Weining, S. Global Identification of MicroRNAs and Their Targets in Barley under Salinity Stress. PLoS ONE 2015, 10, e0137990. [CrossRef] [PubMed]

95. Wu, J.; Wang, L.; Wang, S. MicroRNAs associated with drought response in the pulse crop common bean (Phaseolus vulgaris L.). Gene 2017, 628, 78-86. [CrossRef] [PubMed]

96. Ramirez, M.; Flores-Pacheco, G.; Reyes, J.L.; Alvarez, A.L.; Drevon, J.J.; Girard, L.; Hernandez, G. Two Common Bean Genotypes with Contrasting Response to Phosphorus Deficiency Show Variations in the microRNA 399-Mediated PvPHO2 Regulation within the PvPHR1 Signaling Pathway. Int. J. Mol. Sci. 2013, 14, 8328-8344. [CrossRef] [PubMed]

97. Singh, I.; Smita, S.; Mishra, D.C.; Kumar, S.; Singh, B.K.; Rai, A. Abiotic Stress Responsive miRNA-Target Network and Related Markers (SNP, SSR) in Brassica juncea. Front. Plant Sci. 2017, 8, 1943. [CrossRef] [PubMed]

98. Cui, C.; Wang, J.-J.; Zhao, J.-H.; Fang, Y.-Y.; He, X.-F.; Guo, H.-S.; Duan, C.-G. A Brassica miRNA Regulates Plant Growth and Immunity through Distinct Modes of Action. Mol. Plant 2020, 13, 231-245. [CrossRef] [PubMed]

99. Ping, X.; Wang, T.; Lin, N.; Di, F.; Li, Y.; Jian, H.; Wang, H.; Lu, K.; Li, J.; Xu, X.; et al. Genome-Wide Identification of the LAC Gene Family and Its Expression Analysis Under Stress in Brassica napus. Molecules 2019, 24, 1985. [CrossRef] [PubMed]

100. Jian, H.; Wang, J.; Wang, T.; Wei, L.; Li, J.; Liu, L. Identification of Rapeseed MicroRNAs Involved in Early Stage Seed Germination under Salt and Drought Stresses. Front. Plant Sci. 2016, 7. [CrossRef]

101. Chen, C.-C.; Fu, S.-F.; Norikazu, M.; Yang, Y.-W.; Liu, Y.-J.; Ikeo, K.; Gojobori, T.; Huang, H.-J. Comparative miRNAs analysis of Two contrasting broccoli inbred lines with divergent head-forming capacity under temperature stress. BMC Genom. 2015, 16, 1026. [CrossRef]

102. Ahmed, W.; Xia, Y.; Zhang, H.; Li, R.; Bai, G.; Siddique, K.H.M.; Guo, P. Identification of conserved and novel miRNAs responsive to heat stress in flowering Chinese cabbage using high-throughput sequencing. Sci. Rep. 2019, 9, 1-11. [CrossRef] [PubMed]

103. Wang, Z.; Jiang, D.; Zhang, C.; Tan, H.; Li, Y.; Lv, S.; Hou, X.; Cui, X. Genome-wide identification of turnip mosaic virus-responsive microRNAs in non-heading Chinese cabbage by high-throughput sequencing. Gene 2015, 571, 178-187. [CrossRef] [PubMed]

104. Pinweha, N.; Asvarak, T.; Viboonjun, U.; Narangajavana, J. Involvement of miR160/miR393 and their targets in cassava responses to anthracnose disease. J. Plant Physiol. 2015, 174, 26-35. [CrossRef] [PubMed]

105. Li, M.-Y.; Wang, F.; Xu, Z.-S.; Jiang, Q.; Ma, J.; Tan, G.-F.; Xiong, A.-S. High throughput sequencing of two celery varieties small RNAs identifies microRNAs involved in temperature stress response. BMC Genom. 2014, 15, 242. [CrossRef] [PubMed]

106. Garg, V.; Khan, A.W.; Kudapa, H.; Kale, S.M.; Chitikineni, A.; Qiwei, S.; Sharma, M.; Li, C.; Zhang, B.; Xin, L.; et al. Integrated transcriptome, small RNA and degradome sequencing approaches provide insights into Ascochyta blight resistance in chickpea. Plant Biotechnol. J. 2019, 17, 914-931. [CrossRef] [PubMed]

107. Kohli, D.; Joshi, G.; Deokar, A.A.; Bhardwaj, A.R.; Agarwal, M.; Katiyar-Agarwal, S.; Srinivasan, R.; Jain, P.K. Identification and Characterization of Wilt and Salt Stress-Responsive MicroRNAs in Chickpea through High-Throughput Sequencing. PLoS ONE 2014, 9, e108851. [CrossRef]

108. Wang, W.; Liu, D.; Chen, D.; Cheng, Y.; Zhang, X.; Song, L.; Hu, M.; Dong, J.; Shen, F. MicroRNA414c affects salt tolerance of cotton by regulating reactive oxygen species metabolism under salinity stress. RNA Biol. 2019, 16, 362-375. [CrossRef] [PubMed]

109. Yin, Z.; Li, Y.; Zhu, W.; Fu, X.; Han, X.; Wang, J.; Lin, H.; Ye, W. Identification, Characterization, and Expression Patterns of TCP Genes and microRNA319 in Cotton. Int. J. Mol. Sci. 2018, 19, 3655. [CrossRef]

110. Wang, C.; Katherine, D.; Wang, X.; Zhang, S.; Guo, X. ghr-miR5272a-mediated regulation of GhMKK6 gene transcription contributes to the immune response in cotton. J. Exp. Bot. 2017, 68, 5895-5906. [CrossRef]

111. Yin, Z.; Han, X.; Li, Y.; Wang, J.; Wang, D.; Wang, S.; Fu, X.; Ye, W. Comparative Analysis of Cotton Small RNAs and Their Target Genes in Response to Salt Stress. Genes 2017, 8, 369. [CrossRef]

112. Ding, Y.; Ma, Y.; Liu, N.; Xu, J.; Hu, Q.; Li, Y.; Wu, Y.; Xie, S.; Zhu, L.; Min, L.; et al. microRNAs involved in auxin signalling modulate male sterility under high-temperature stress in cotton (Gossypium hirsutum). Plant J. 2017, 91, 977-994. [CrossRef] 
113. Wang, Q.; Liu, N.; Yang, X.; Tu, L.; Zhang, X. Small RNA-mediated responses to low- and high-temperature stresses in cotton. Sci. Rep. 2016, 6, 35558. [CrossRef]

114. Yin, Z.; Li, Y.; Yu, J.; Liu, Y.; Li, C.; Han, X.; Shen, F. Difference in miRNA expression profiles between two cotton cultivars with distinct salt sensitivity. Mol. Biol. Rep. 2011, 39, 4961-4970. [CrossRef]

115. Barrera-Figueroa, B.E.; Gao, L.; Diop, N.N.; Wu, Z.; Ehlers, J.D.; Roberts, P.A.; Close, T.J.; Zhu, J.-K.; Liu, R. Identification and comparative analysis of drought-associated microRNAs in two cowpea genotypes. BMC Plant Biol. 2011, 11, 127. [CrossRef] [PubMed]

116. Yaish, M.W.; Sunkar, R.; Zheng, Y.; Ji, B.; Al-Yahyai, R.; Farooq, S.A. A genome-wide identification of the miRNAome in response to salinity stress in date palm (Phoenix dactylifera L.). Front. Plant Sci. 2015, 6, 946. [CrossRef]

117. Dmitriev, A.A.; Kudryavtseva, A.V.; Bolsheva, N.L.; Zyablitsin, A.V.; Rozhmina, T.A.; Kishlyan, N.V.; Krasnov, G.S.; Speranskaya, A.S.; Krinitsina, A.A.; Sadritdinova, A.F.; et al. miR319, miR390, and miR393 Are Involved in Aluminum Response in Flax (Linum usitatissimum L.). BioMed Res. Int. 2017, 2017, 1-6. [CrossRef]

118. Wang, Y.; Li, L.; Tang, S.; Liu, J.; Zhang, H.; Zhi, H.; Jia, G.; Diao, X. Combined small RNA and degradome sequencing to identify miRNAs and their targets in response to drought in foxtail millet. BMC Genet. 2016, 17, 57. [CrossRef] [PubMed]

119. Yadav, A.; Khan, Y.; Prasad, M. Dehydration-responsive miRNAs in foxtail millet: Genome-wide identification, characterization and expression profiling. Planta 2015, 243, 749-766. [CrossRef]

120. Jiang, Q.; Wang, F.; Tan, H.-W.; Li, M.-Y.; Xu, Z.-S.; Tan, G.-F.; Xiong, A.-S. De novo transcriptome assembly, gene annotation, marker development, and miRNA potential target genes validation under abiotic stresses in Oenanthe javanica. Mol. Genet. Genom. 2015, 290, 671-683. [CrossRef]

121. Aydinoglu, F. Elucidating the regulatory roles of microRNAs in maize (Zea mays L.) leaf growth response to chilling stress. Planta 2020, 251, 38. [CrossRef]

122. Zhang, M.; An, P.; Li, H.; Wang, X.; Zhou, J.; Dong, P.; Zhao, Y.; Wang, Q.; Li, C. The miRNA-Mediated Post-Transcriptional Regulation of Maize in Response to High Temperature. Int. J. Mol. Sci. 2019, 20, 1754. [CrossRef] [PubMed]

123. Yang, Z.; Wang, Z.; Yang, C.; Yang, Z.; Li, H.; Wu, Y. Physiological responses and small RNAs changes in maize under nitrogen deficiency and resupply. Genes Genom. 2019, 41, 1183-1194. [CrossRef]

124. Wang, B.; Cheng, D.; Chen, Z.; Zhang, M.; Zhang, G.; Jiang, M.; Tan, M. Bioinformatic Exploration of the Targets of Xylem Sap miRNAs in Maize under Cadmium Stress. Int. J. Mol. Sci. 2019, 20, 1474. [CrossRef] [PubMed]

125. Nie, Z.; Ren, Z.; Wang, L.; Su, S.; Wei, X.; Zhang, X.; Wu, L.; Liu, D.; Tang, H.; Liu, H.; et al. Genome-wide identification of microRNAs responding to early stages of phosphate deficiency in maize. Physiol. Plant 2016, 157, 161-174. [CrossRef]

126. Zhai, L.; Liu, Z.; Zou, X.; Jiang, Y.; Qiu, F.; Zheng, Y.; Zhang, Z. Genome-wide identification and analysis of microRNA responding to long-term waterlogging in crown roots of maize seedlings. Physiol. Plant 2012, 147, 181-193. [CrossRef]

127. Zhao, M.; Tai, H.; Sun, S.; Zhang, F.; Xu, Y.; Li, W.-X. Cloning and Characterization of Maize miRNAs Involved in Responses to Nitrogen Deficiency. PLoS ONE 2012, 7, e29669. [CrossRef] [PubMed]

128. Liu, Z.; Kumari, S.; Zhang, L.; Zheng, Y.; Ware, D. Characterization of miRNAs in Response to Short-Term Waterlogging in Three Inbred Lines of Zea mays. PLoS ONE 2012, 7, e39786. [CrossRef]

129. Xu, Z.; Zhong, S.; Li, X.; Li, W.; Rothstein, S.J.; Zhang, S.; Bi, Y.; Xie, C. Genome-Wide Identification of MicroRNAs in Response to Low Nitrate Availability in Maize Leaves and Roots. PLoS ONE 2011, 6, e28009. [CrossRef]

130. Li, S.; Shao, Z.; Fu, X.; Xiao, W.; Li, L.; Chen, M.; Sun, M.; Li, D.; Gao, D. Identification and characterization of Prunus persica miRNAs in response to UVB radiation in greenhouse through high-throughput sequencing. BMC Genom. 2017, 18, 938. [CrossRef] [PubMed]

131. Liu, J.; Zhang, X.; Zhang, F.; Hong, N.; Wang, G.; Wang, A.; Wang, L. Identification and characterization of microRNAs from in vitro-grown pear shoots infected with Apple stem grooving virus in response to high temperature using small RNA sequencing. BMC Genom. 2015, 16, 1-16. [CrossRef]

132. Tiwari, J.K.; Buckseth, T.; Zinta, R.; Saraswati, A.; Singh, R.K.; Rawat, S.; Chakrabarti, S.K. Genome-wide identification and characterization of microRNAs by small RNA sequencing for low nitrogen stress in potato. PLoS ONE 2020, 15, e0233076. [CrossRef] [PubMed]

133. Zhang, L.; Yao, L.; Zhang, N.; Yang, J.; Zhu, X.; Tang, X.; Calderón-Urrea, A.; Si, H. Lateral Root Development in Potato Is Mediated by Stu-mi164 Regulation of NAC Transcription Factor. Front. Plant Sci. 2018, 9, 383. [CrossRef] [PubMed]

134. Yang, J.; Zhang, N.; Ma, C.; Qu, Y.; Si, H.; Wang, D. Prediction and verification of microRNAs related to proline accumulation under drought stress in potato. Comput. Biol. Chem. 2013, 46, 48-54. [CrossRef] [PubMed]

135. Yang, Z.; Li, W.; Su, X.; Ge, P.; Zhou, Y.; Hao, Y.; Shu, H.; Gao, C.; Cheng, S.; Zhu, G.; et al. Early Response of Radish to Heat Stress by Strand-Specific Transcriptome and miRNA Analysis. Int. J. Mol. Sci. 2019, 20, 3321. [CrossRef]

136. Xu, L.; Wang, Y.; Liu, W.; Wang, J.; Zhu, X.; Zhang, K.; Yu, R.; Wang, R.; Xie, Y.; Zhang, W.; et al. De novo sequencing of root transcriptome reveals complex cadmium-responsive regulatory networks in radish (Raphanus sativus L.). Plant Sci. 2015, 236, 313-323. [CrossRef]

137. Liu, W.; Xu, L.; Wang, Y.; Shen, H.; Zhu, X.; Zhang, K.; Chen, Y.; Yu, R.; Limera, C.; Liu, L. Transcriptome-wide analysis of chromium-stress responsive microRNAs to explore miRNA-mediated regulatory networks in radish (Raphanus sativus L.). Sci. Rep. 2015, 5, 14024. [CrossRef] 
138. Sun, X.; Xu, L.; Wang, Y.; Keyun, Z.; Zhu, X.; Luo, X.; Gong, Y.; Wang, R.; Limera, C.; Zhang, K.; et al. Identification of novel and salt-responsive miRNAs to explore miRNA-mediated regulatory network of salt stress response in radish (Raphanus sativus L.). BMC Genom. 2015, 16, 1-16. [CrossRef]

139. Xu, L.; Wang, Y.; Zhai, L.; Xu, Y.; Wang, L.; Zhu, X.; Gong, Y.; Yu, R.; Limera, C.; Liu, L. Genome-wide identification and characterization of cadmium-responsive microRNAs and their target genes in radish (Raphanus sativus L.) roots. J. Exp. Bot. 2013, 64, 4271-4287. [CrossRef]

140. Liu, A.; Zhou, Z.; Yi, Y.; Chen, G. Transcriptome analysis reveals the roles of stem nodes in cadmium transport to rice grain. BMC Genom. 2020, 21, 1-16. [CrossRef]

141. Tang, Z.; Xu, M.; Ito, H.; Cai, J.; Ma, X.; Qin, J.; Yu, D.; Meng, Y. Deciphering the non-coding RNA-level response to arsenic stress in rice (Oryza sativa). Plant Signal. Behav. 2019, 14, 1629268. [CrossRef]

142. Goel, S.; Goswami, K.; Pandey, V.K.; Pandey, M.; Sanan-Mishra, N. Identification of microRNA-target modules from rice variety Pusa Basmati-1 under high temperature and salt stress. Funct. Integr. Genom. 2019, 19, 867-888. [CrossRef]

143. Jiang, W.; Shi, W.; Ma, X.; Zhao, J.; Wang, S.; Tan, L.; Sun, C.; Liu, F. Identification of microRNAs responding to cold stress in Dongxiang common wild rice. Genome 2019, 62, 635-642. [CrossRef]

144. Shin, S.-Y.; Jeong, J.S.; Lim, J.Y.; Kim, T.; Park, J.H.; Kim, J.-K.; Shin, C. Transcriptomic analyses of rice (Oryza sativa) genes and non-coding RNAs under nitrogen starvation using multiple omics technologies. BMC Genom. 2018, 19, 1-20. [CrossRef]

145. Yue, E.; Liu, Z.; Li, C.; Li, Y.; Liu, Q.; Xu, J.-H. Overexpression of miR529a confers enhanced resistance to oxidative stress in rice (Oryza sativa L.). Plant Cell Rep. 2017, 36, 1171-1182. [CrossRef]

146. Lu, Y.; Feng, Z.; Liu, X.; Bian, L.; Xie, H.; Zhang, C.; Mysore, K.S.; Liang, J. MiR393 and miR390 synergistically regulate lateral root growth in rice under different conditions. BMC Plant Biol. 2018, 18, 261. [CrossRef]

147. Sharma, N.; Tripathi, A.; Sanan-Mishra, N. Profiling the expression domains of a rice-specific microRNA under stress. Front. Plant Sci. 2015, 6. [CrossRef]

148. Secco, D.; Jabnoune, M.; Walker, H.; Shou, H.; Wu, P.; Poirier, Y.; Whelan, J. Spatio-Temporal Transcript Profiling of Rice Roots and Shoots in Response to Phosphate Starvation and Recovery. Plant Cell 2013, 25, 4285-4304. [CrossRef] [PubMed]

149. Cai, H.; Lu, Y.; Xie, W.; Zhu, T.; Lian, X. Transcriptome response to nitrogen starvation in rice. J. Biosci. 2012, 37, 731-747. [CrossRef] [PubMed]

150. Nischal, L.; Mohsin, M.; Khan, I.; Kardam, H.; Wadhwa, A.; Abrol, Y.P.; Iqbal, M.; Ahmad, A. Identification and Comparative Analysis of MicroRNAs Associated with Low-N Tolerance in Rice Genotypes. PLoS ONE 2012, 7, e50261. [CrossRef]

151. Barrera-Figueroa, B.E.; Gao, L.; Wu, Z.; Zhou, X.; Zhu, J.; Jin, H.; Liu, R.; Zhu, J.-K. High throughput sequencing reveals novel and abiotic stress-regulated microRNAs in the inflorescences of rice. BMC Plant Biol. 2012, 12, 132. [CrossRef] [PubMed]

152. Macovei, A.; Tuteja, N. microRNAs targeting DEAD-box helicases are involved in salinity stress response in rice (Oryza sativa L.). BMC Plant Biol. 2012, 12, 183. [CrossRef]

153. Zheng, Y.; Hivrale, V.; Zhang, X.; Valliyodan, B.; Lelandais-Brière, C.; Farmer, A.D.; May, G.D.; Crespi, M.; Nguyen, H.T.; Sunkar, R. Small RNA profiles in soybean primary root tips under water deficit. BMC Syst. Biol. 2016, 10, 1-10. [CrossRef]

154. Liu, X.; Zhang, R.; Ou, H.; Gui, Y.; Wei, J.; Zhou, H.; Tan, H.; Li, Y. Comprehensive transcriptome analysis reveals genes in response to water deficit in the leaves of Saccharum narenga (Nees ex Steud.) hack. BMC Plant Biol. 2018, 18, 250. [CrossRef] [PubMed]

155. Yang, Y.; Zhang, X.; Su, Y.; Zou, J.; Wang, Z.; Xu, L.; Que, Y. miRNA alteration is an important mechanism in sugarcane response to low-temperature environment. BMC Genom. 2017, 18, 833. [CrossRef]

156. Khan, M.S.; Khraiwesh, B.; Pugalenthi, G.; Gupta, R.S.; Singh, J.; Duttamajumder, S.K.; Kapur, R. Subtractive hybridizationmediated analysis of genes andin silicoprediction of associated microRNAs under waterlogged conditions in sugarcane (Saccharum spp.). FEBS Open Bio 2014, 4, 533-541. [CrossRef]

157. Gentile, A.; Ferreira, T.H.; Mattos, R.S.; Dias, L.I.; Hoshino, A.A.; Carneiro, M.S.; Souza, G.M.; Calsa, T.; Nogueira, R.M.; Endres, L.; et al. Effects of drought on the microtranscriptome of field-grown sugarcane plants. Planta 2012, 237, 783-798. [CrossRef]

158. Ferreira, T.H.; Gentile, A.; Vilela, R.D.; Costa, G.G.L.; Dias, L.I.; Endres, L.; Menossi, M. microRNAs Associated with Drought Response in the Bioenergy Crop Sugarcane (Saccharum spp.). PLoS ONE 2012, 7, e46703. [CrossRef] [PubMed]

159. Saminathan, T.; Alvarado, A.; Lopez, C.; Shinde, S.; Gajanayake, B.; Abburi, V.L.; Vajja, V.G.; Jagadeeswaran, G.; Reddy, K.R.; Nimmakayala, P.; et al. Elevated carbon dioxide and drought modulate physiology and storage-root development in sweet potato by regulating microRNAs. Funct. Integr. Genom. 2018, 19, 171-190. [CrossRef]

160. Yang, Z.; Zhu, P.; Kang, H.; Liu, L.; Cao, Q.; Sun, J.; Dong, T.; Zhu, M.; Li, Z.; Xu, T. High-throughput deep sequencing reveals the important role that microRNAs play in the salt response in sweet potato (Ipomoea batatas L.). BMC Genom. 2020, 21, 1-16. [CrossRef] [PubMed]

161. Hivrale, V.; Zheng, Y.; Puli, C.O.R.; Jagadeeswaran, G.; Gowdu, K.; Kakani, V.G.; Barakat, A.; Sunkar, R. Characterization of drought- and heat-responsive microRNAs in switchgrass. Plant Sci. 2016, 242, 214-223. [CrossRef] [PubMed]

162. Sun, G.; Stewart, C.N.; Xiao, P.; Zhang, B. MicroRNA Expression Analysis in the Cellulosic Biofuel Crop Switchgrass (Panicum virgatum) under Abiotic Stress. PLoS ONE 2012, 7, e32017. [CrossRef] [PubMed]

163. Xu, J.; Chen, Q.; Liu, P.; Jia, W.; Chen, Z.; Xu, Z. Integration of mRNA and miRNA Analysis Reveals the Molecular Mechanism Underlying Salt and Alkali Stress Tolerance in Tobacco. Int. J. Mol. Sci. 2019, 20, 2391. [CrossRef] 
164. Zhou, R.; Yu, X.; Ottosen, C.-O.; Zhang, T.; Wu, Z.; Zhao, T. Unique miRNAs and their targets in tomato leaf responding to combined drought and heat stress. BMC Plant Biol. 2020, 20, 1-10. [CrossRef] [PubMed]

165. Liu, M.; Yu, H.; Zhao, G.; Huang, Q.; Lu, Y.; Ouyang, B. Profiling of drought-responsive microRNA and mRNA in tomato using high-throughput sequencing. BMC Genom. 2017, 18, 1-18. [CrossRef]

166. Zeng, X.; Xu, Y.; Jiang, J.; Zhang, F.; Ma, L.; Wu, D.; Wang, Y.; Sun, W. Identification of cold stress responsive microRNAs in two winter turnip rape (Brassica rapa L.) by high throughput sequencing. BMC Plant Biol. 2018, 18, 52. [CrossRef] [PubMed]

167. Cao, J.; Gulyás, Z.; Kalapos, B.; Boldizsár, Á.; Liu, X.; Pál, M.; Yao, Y.; Galiba, G.; Kocsy, G. Identification of a redox-dependent regulatory network of miRNAs and their targets in wheat. J. Exp. Bot. 2019, 70, 85-99. [CrossRef]

168. Liu, H.; Able, A.J.; Able, J.A. Genotypic performance of Australian durum under single and combined water-deficit and heat stress during reproduction. Sci. Rep. 2019, 9, 1-17. [CrossRef]

169. Bai, Q.; Wang, X.; Chen, X.; Shi, G.; Liu, Z.; Guo, C.; Xiao, K. Wheat miRNA TaemiR408 Acts as an Essential Mediator in Plant Tolerance to Pi Deprivation and Salt Stress via Modulating Stress-Associated Physiological Processes. Front. Plant Sci. 2018, 9 , 499. [CrossRef]

170. Liu, Z.; Wang, X.; Chen, X.; Shi, G.; Bai, Q.; Xiao, K. TaMIR1139: A wheat miRNA responsive to Pi-starvation, acts a critical mediator in modulating plant tolerance to Pi deprivation. Plant Cell Rep. 2018, 37, 1293-1309. [CrossRef]

171. Song, G.; Zhang, R.; Zhang, S.; Li, Y.; Gao, J.; Han, X.; Chen, M.; Wang, J.; Li, W.; Li, G. Response of microRNAs to cold treatment in the young spikes of common wheat. BMC Genom. 2017, 18, 212. [CrossRef]

172. Chen, X.-Y.; Yang, Y.; Ran, L.-P.; Dong, Z.-D.; Zhang, E.-J.; Yu, X.-R.; Xiong, F. Novel Insights into miRNA Regulation of Storage Protein Biosynthesis during Wheat Caryopsis Development under Drought Stress. Front. Plant Sci. 2017, 8, 1707. [CrossRef] [PubMed]

173. Akdogan, G.; Tufekci, E.D.; Uranbey, S.; Unver, T. miRNA-based drought regulation in wheat. Funct. Integr. Genom. 2016, 16, 221-233. [CrossRef] [PubMed]

174. Wang, B.; Sun, Y.-F.; Song, N.; Wei, J.-P.; Wang, X.-J.; Feng, H.; Yin, Z.-Y.; Kang, Z.-S. MicroRNAs involving in cold, wounding and salt stresses in Triticum aestivum L. Plant Physiol. Biochem. 2014, 80, 90-96. [CrossRef]

175. Feng, H.; Zhang, Q.; Wang, Q.; Wang, X.; Liu, J.; Li, M.; Huang, L.; Kang, Z. Target of tae-miR408, a chemocyanin-like protein gene (TaCLP1), plays positive roles in wheat response to high-salinity, heavy cupric stress and stripe rust. Plant Mol. Biol. 2013, 83, 433-443. [CrossRef]

176. Sablok, G.; Pérez-Quintero, Á.L.; Hassan, M.; Tatarinova, T.V.; López, C. Artificial microRNAs (amiRNAs) engineering-On how microRNA-based silencing methods have affected current plant silencing research. Biochem. Biophys. Res. Commun. 2011, 406, 315-319. [CrossRef] [PubMed]

177. Zhang, N.; Zhang, D.; Chen, S.L.; Gong, B.-Q.; Guo, Y.; Xu, L.; Zhang, X.-N.; Li, J.-F. Engineering Artificial MicroRNAs for Multiplex Gene Silencing and Simplified Transgenic Screen. Plant Physiol. 2018, 178, 989-1001. [CrossRef] [PubMed]

178. Kis, A.; Tholt, G.; Ivanics, M.; Várallyay, É.; Jenes, B.; Havelda, Z. Polycistronic artificial miRNA-mediated resistance toWheat dwarf virusin barley is highly efficient at low temperature. Mol. Plant Pathol. 2015, 17, 427-437. [CrossRef] [PubMed]

179. Wagaba, H.; Patil, B.L.; Mukasa, S.; Alicai, T.; Fauquet, C.M.; Taylor, N.J. Artificial microRNA-derived resistance to Cassava brown streak disease. J. Virol. Methods 2016, 231, 38-43. [CrossRef]

180. Niu, Q.-W.; Lin, S.-S.; Reyes, J.L.; Chen, K.-C.; Wu, H.-W.; Yeh, S.-D.; Chua, N.-H. Expression of artificial microRNAs in transgenic Arabidopsis thaliana confers virus resistance. Nat. Biotechnol. 2006, 24, 1420-1428. [CrossRef]

181. Agrawal, A.; Rajamani, V.; Reddy, V.S.; Mukherjee, S.K.; Bhatnagar, R.K. Transgenic plants over-expressing insect-specific microRNA acquire insecticidal activity against Helicoverpa armigera: An alternative to Bt-toxin technology. Transgenic Res. 2015, 24, 791-801. [CrossRef]

182. Peng, T.; Qiao, M.; Liu, H.; Teotia, S.; Zhang, Z.; Zhao, Y.; Wang, B.; Zhao, D.; Shi, L.; Zhang, C.; et al. A Resource for Inactivation of MicroRNAs Using Short Tandem Target Mimic Technology in Model and Crop Plants. Mol. Plant 2018, 11, 1400-1417. [CrossRef]

183. Zhang, H.; Zhang, J.; Yan, J.; Gou, F.; Mao, Y.; Tang, G.; Botella, J.R.; Zhu, J.-K. Short tandem target mimic rice lines uncover functions of miRNAs in regulating important agronomic traits. Proc. Natl. Acad. Sci. USA 2017, 114, 5277-5282. [CrossRef] [PubMed]

184. Reichel, M.; Li, Y.; Li, J.; Millar, A.A. Inhibiting plant microRNA activity: Molecular SPONGEs, target MIMICs and STTMs all display variable efficacies against target microRNAs. Plant Biotechnol. J. 2015, 13, 915-926. [CrossRef] [PubMed]

185. Franco-Zorrilla, J.M.; Valli, A.; Todesco, M.; Mateos, I.; Puga, M.I.; Rubio-Somoza, I.; Leyva, A.; Weigel, D.; García, J.A.; PazAres, J. Target mimicry provides a new mechanism for regulation of microRNA activity. Nat. Genet. 2007, 39, $1033-1037$. [CrossRef] [PubMed]

186. Todesco, M.; Rubio-Somoza, I.; Paz-Ares, J.; Weigel, D. A Collection of Target Mimics for Comprehensive Analysis of MicroRNA Function in Arabidopsis thaliana. PLoS Genet. 2010, 6, e1001031. [CrossRef]

187. Liu, X.; Wu, S.; Xu, J.; Sui, C.; Wei, J. Application of CRISPR/Cas9 in plant biology. Acta Pharm. Sin. B 2017, 7, $292-302$. [CrossRef] [PubMed]

188. Yin, K.; Gao, C.; Qiu, J.-L. Progress and prospects in plant genome editing. Nat. Plants 2017, 3, 17107. [CrossRef]

189. Barrangou, R.; Birmingham, A.; Wiemann, S.; Beijersbergen, R.L.; Hornung, V.; Smith, A.V.B. Advances in CRISPR-Cas9 genome engineering: Lessons learned from RNA interference. Nucleic Acids Res. 2015, 43, 3407-3419. [CrossRef] [PubMed]

190. Basak, J.; Nithin, C. Targeting Non-Coding RNAs in Plants with the CRISPR-Cas Technology is a Challenge yet Worth Accepting. Front. Plant Sci. 2015, 6, 1001. [CrossRef] 
191. Jacobs, T.B.; Lafayette, P.R.; Schmitz, R.J.; Parrott, W.A. Targeted genome modifications in soybean with CRISPR/Cas9. BMC Biotechnol. 2015, 15, 1-10. [CrossRef]

192. Li, M.; Li, X.; Zhou, Z.; Wu, P.; Fang, M.; Pan, X.; Lin, Q.; Luo, W.; Wu, G.; Li, H. Reassessment of the Four Yield-related Genes Gn1a, DEP1, GS3, and IPA1 in Rice Using a CRISPR/Cas9 System. Front. Plant Sci. 2016, 7, 377. [CrossRef] [PubMed]

193. Zhou, J.; Deng, K.; Cheng, Y.; Zhong, Z.; Tian, L.; Tang, X.; Tang, A.; Zheng, X.; Zhang, T.; Qi, Y.; et al. CRISPR-Cas9 Based Genome Editing Reveals New Insights into MicroRNA Function and Regulation in Rice. Front. Plant Sci. 2017, 8, 1598. [CrossRef] [PubMed]

194. Paschoal, A.R.; Chavez, I.L.; Domingues, D.S.; Stadler, P.F. CeRNAs in plants: Computational approaches and associated challenges for target mimic research. Brief. Bioinform. 2017, 19, 1273-1289. [CrossRef] [PubMed] 